OECDpublishing

\title{
BUILDING THE
}

RESILIENCE OF TURKEY'S

AGRICULTURAL SECTOR

TO DROUGHTS

OECD FOOD,

AGRICULTURE AND

FISHERIES PAPER

September $2021 \quad \mathbf{n}^{\circ} \mathbf{1 6 7}$ 


\title{
Building the Resilience of Turkey's Agricultural Sector to Droughts
}

\author{
Morvarid Bagherzadeh and Makiko Shigemitsu
}

\begin{abstract}
Turkey is exposed to multiple natural hazard-induced disasters (NHID) and has considerable experience in managing the associated risks. Drought, in particular, has had significant impacts on the country's agricultural sector, and the frequency of droughts is expected to increase due to climate change. Existing governance and policy frameworks seek to ensure that the agricultural sector is prepared for, and able to respond to, adverse events as they occur. While these mechanisms contribute to improved resilience, further opportunities exist to strengthen policy processes, in particular by increasing farmer and private sector participation.
\end{abstract}

Keywords: Climate change, agricultural risk management, irrigation, insurance

JEL codes: Q54, Q18, Q15, Q16, Q25, Q28

\section{Acknowledgements}

This case study is one of seven prepared for the joint OECD-FAO project on Building Agricultural Resilience to Natural Hazard-Induced Disasters: Insights from Country Case Studies, which was funded by a voluntary contribution from the Italian Government.

The support of the government of Turkey made this case study possible. Authors would like to thank the team in the Department of International Organizations of the Ministry of Agriculture and Forestry (MAF) for their coordination role and experts in the Directorate Generals of the MAF involved in the resilience frameworks for their contributions, openness and availability. Finally, the authors wish to thank OECD colleagues for their valuable comments and assistance in preparing this report. 


\section{Table of contents}

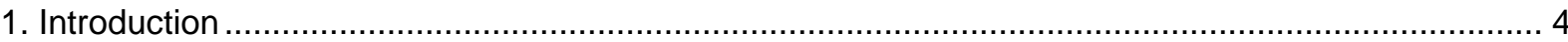

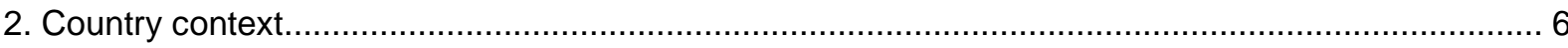

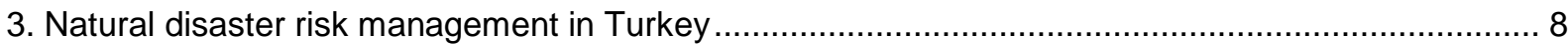

3.1. Governance frameworks affecting disaster risk management in agriculture ........................... 8

3.2. Risk identification, assessment and awareness ............................................................ 13

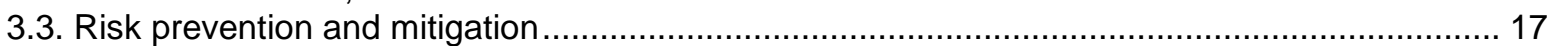

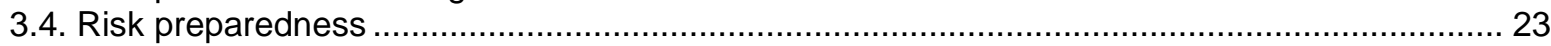

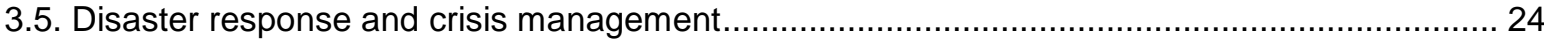

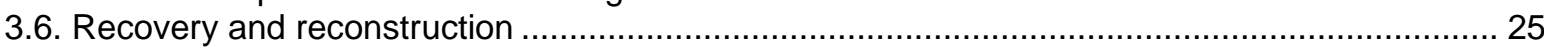

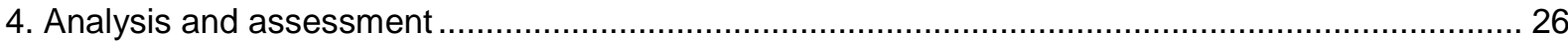

4.1. Disaster risk management in Turkey follows an all-hazards approach, but a more holistic implementation is needed that integrates various policy objectives with clearer roles and responsibilities among actors, including the private sector

4.2. Turkey's investments in strengthening natural hazard risk identification and assessment should be treated as a public good and used to raise stakeholders' awareness of their exposure to risks and inform their actions

4.3. Turkey invests in structural and non-structural measures to mitigate and prevent drought risks,

but water policies need be strengthened to better manage water resources.... 28

4.4. While the Government centralises disaster response, more could be done to support on-farm response capacities and encourage farm sector participation in a shared responsibility for a resilient recovery

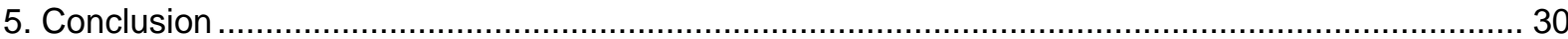

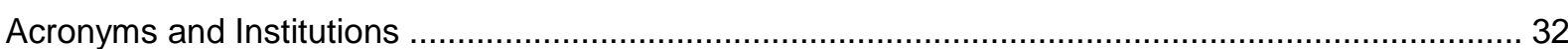

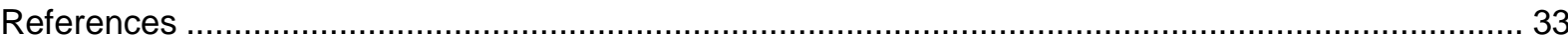

\section{FIGURES}

Figure 1. Level and composition of support to agriculture (2007-2019) 10

Figure 2. Disaster risk management governance and frameworks for agricultural droughts in Turkey 13

\section{TABLES}

Table 1. Policy targets for agriculture in the Eleventh Development Plan (2019-2023) 


\section{Key messages}

\section{What is the issue and why is it important?}

- Turkey's agricultural sector is exposed to a range of natural hazards. Droughts are increasingly observed in many regions, and their frequency and severity are expected to increase due to climate change. Moreover, because agriculture is Turkey's largest water user, the sector may also directly contribute to the country's overall water stress.

- Turkey's agricultural sector must increase its overall resilience to drought, strengthening its ability to prepare and plan for, absorb the impact of, and recover from drought and more successfully adapt and transform in response to drought events, while ensuring that these efforts do not exacerbate current and future water stress.

\section{What did we learn?}

Various initiatives are positioning Turkey for improved resilience to natural hazards:

- Turkey embraces an all-hazards approach for its disaster risk management. Turkey also implements several frameworks that prepare and plan for agricultural drought risks.

- Drought risk research, data collection and assessment are well structured and inform government disaster risk management decisions and preparedness for adverse events.

- Policy makers recognise the benefits of ex ante approaches. The government invests in conventional and modernised irrigation infrastructure. It also implements non-structural measures, including improving access to agricultural insurance.

That said, the policy portfolio for managing drought under-emphasises investments in on-farm preparedness and adaptation, and sustainable water use.

\section{Key recommendations}

- On-farm preparedness and adaptation to drought risks is a key dimension of agricultural resilience. The government can support this by improving data access and enabling private sector participation in the policy planning process.

- Turkey can strengthen on-farm capacity to implement strategies for agricultural productivity and sustainability. Investments in training and extension services that are tailored to the needs and capacities of farmers are necessary to minimise the knowledge gap and accelerate on-farm adoption of all resilience strategies.

- The policy emphasis on access to water and irrigation should be widened to encourage water management to mitigate and prevent drought impacts. Turkey should strengthen local water allocation regimes and incentivise water saving. Water fees should be used to cover the operation and administration costs of irrigation networks. The gradual implementation of water metering and use monitoring, combined with the provision of water-related extension services, would be an important step in this direction.

- Closer attention should be paid to the linkages and trade-offs between agricultural policies that support certain commodity production and sustainable water use. Commodity payments can encourage water use, increasing water stress. The transition away from commodity support to the provision of sector-wide services that enhance the sector's capacity to prepare, prevent, absorb and reconstruct are important steps in the direction of a more drought resilient agricultural sector. 


\section{Introduction}

Turkey is exposed to a broad range of natural hazards. Floods, drought, frost and avalanches are all common as a result of the country's climatic and geographic diversity, and the country is also exposed to earthquakes and landslides. Of these hazards, droughts are increasingly common in many regions of the country, particularly those where agriculture is prominent.

This case study examines how governance arrangements and policy measures help to build the resilience of farmers and the agricultural sector to natural hazard-induced disasters (NHID) in Turkey. ${ }^{1}$ It is one of seven case studies prepared for the joint OECD-FAO project on Building agricultural resilience to natural disasters (OECD/FAO, 2021 $[1]) .{ }^{2}$ The project examines Disaster Risk Management (DRM) frameworks in selected OECD and developing countries to identify what governments and agricultural sector stakeholders can do to build resilience to natural hazard-induced disasters - defined here as the ability of farmers to prepare and plan for, absorb, respond, recover from, and more successfully adapt and transform in response to natural hazards (OECD, 2020[2]). The project identifies good practices for building resilience at each stage of the DRM cycle - risk identification, assessment and awareness; prevention and mitigation; preparedness; response and crisis management; and recovery and reconstruction - where good practices are identified according to four principles for effective disaster risk management for resilience (Box 1).

Each of the country case studies in this project focuses on a particular type of natural hazard in order to explore how different policy measures, governance arrangements, on-farm strategies and other initiatives contribute to building resilience. The Turkey case study focuses on drought. Droughts can significantly affect not only the livelihoods of farmers and the rural poor in Turkey, but also its export-oriented value chains. The frequency and severity of droughts are expected to increase as a result of climate change (OECD, 2020[3]; CSB, 2018[4] $)$. For example, an increase in the frequency, intensity and duration of droughts has been forecast for the south, southeast and west of Turkey, with the Mediterranean region identified as a climate change hotspot (Baglee et al., 2013[5]; CSB, 2018[4]; IPCC, 2007[6]). At the same time, Turkey's agricultural sector is the largest user of water, such that the sector is not only affected by drought, but may also be directly contributing to the country's overall water stress. Hence, policies and investments are needed to increase the sector's preparedness for drought and support the capacity of the sector to produce and participate in markets given projected drier conditions under climate change. These policies must also take into account the need to relieve current and future water stresses - for agriculture, but also for the wider community. This case study considers how current policy frameworks and measures help to build the resilience of Turkey's agricultural sector to drought.

\footnotetext{
${ }^{1}$ Resilience as a notion is context-specific and it is a deliberate choice of this project to focus on the resilience of farms and primary producers, notwithstanding that this also has effects on the wider food system.

${ }^{2}$ The seven case study countries are Chile, Italy (Baldwin and Casalini, 2021 [84]), Japan (Shigemitsu and Gray, 2021 [82]), Namibia, New Zealand (Casalini, Bagherzadeh and Gray, 2021 [83]), Turkey and the United States (Gray and Baldwin, $\left.2021_{[81]}\right)$.
} 


\section{Box 1. Principles for effective disaster risk management for resilience}

In 2017, G7 Agriculture Ministers in Bergamo recognised the effects of natural hazards on farmers' lives, agro-food systems, agricultural production and productivity in regions all over the world, and that climate change is projected to amplify many of these impacts. Ministers also noted the importance of strengthening the resilience of farmers to natural hazard (G7 Agriculture Ministers, 2017[7]).

Responding to this imperative, the joint OECD-FAO project on Building agricultural resilience to natural disasters identifies good practices for building agricultural resilience at each stage of the DRM cycle. Good practices in the case study countries are identified according to principles and recommendations from key international frameworks for managing the risks posed by disasters and other critical shocks, including OECD recommendations and the Sendai Framework. ${ }^{1}$ Based on these frameworks, each case study assesses their country-specific situation according to the following four Principles for Effective DRM for Resilience:

1. An inclusive, holistic and all-hazards approach to natural disaster risk governance for resilience:

2. A shared understanding of natural disaster risk based on the identification, assessment and communication of risk, vulnerability and resilience capacities.

3. An ex ante approach to natural disaster risk management.

4. An approach emphasising preparedness and planning for effective crisis management, disaster response, and to "build back better"2 to increase resilience to future natural hazards.

Good practices encompass policy measures and governance arrangements that encourage public and private stakeholders to address gaps in their resilience levels. This can be done by helping stakeholders understand the risks that they face from natural hazards and their responsibilities for managing the risks they pose to their assets. For example, while rarer catastrophic risks such as NHID may require public intervention, on-farm strategies and the individual farmer's overall capacity to manage risk also play a critical role in reducing risk exposure to catastrophic events, particularly over the long term (OECD, $2009_{[8]}$; OECD, 2020[2]). Specifically, good practices that build agricultural resilience to natural hazards are policies and governance arrangements that:

- Encourage public and private actors to consider the risk landscape over the long term, including to take into account the potential future effects of climate change on the agricultural sector, and to place a greater emphasis on what can be done ex ante to reduce risk exposure and increase preparedness.

- Provide incentives and support the capacity of farmers to prevent, mitigate, prepare and plan for, absorb, respond, recover from, and more successfully adapt and transform in response to natural hazards.

- Consider a wide range of future scenarios, including expected environmental, economic and social structural change, and contribute to agricultural productivity and sustainability, even in the absence of a shock or stress.

- Take into account the trade-offs inherent in natural disaster risk management, including between measures to build the capacities of the sector to absorb, adapt, or transform in response to natural disaster risk, and between investing in risk prevention and mitigation ex ante and providing ex post disaster assistance.

- Are developed with the participation of a wide range of actors, to ensure that all relevant stakeholders are equally involved in the design, planning, implementation, monitoring and evaluation of interventions; and share a common understanding of the risk landscape and their respective responsibilities for managing natural disaster risk.

Notes: 1. OECD's Approach to Risk Management for Resilience (OECD, 2009[8]; OECD, 2011 [9]; OECD, 2020[2]); the Sendai Framework for Disaster Risk Reduction (UNISDR, 2015[10]); the OECD Recommendation on the Governance of Critical Risks (OECD, 2014[11]); and the Joint Framework for Strengthening resilience for food security and nutrition of the Rome-based Agencies (FAO, IFAD and WFP, 2019 $\left.{ }_{[12]}\right)$.

2. Building back better is defined as using the recovery, rehabilitation and reconstruction phases after a disaster to increase the resilience of nations and communities through integrating disaster risk reduction measures into the restoration of physical infrastructure and societal systems, and into the revitalization of livelihoods, economies and the environment (UNISDR, 2015 [10]). 


\section{Country context}

Turkey is self-sufficient in food production and a net exporter of agricultural products. Agricultural products such as nuts and dried fruits provide substantial export earnings (OECD, 2020[13]). Primary agriculture accounts for about $6 \%$ of GDP and employs $18 \%$ of the workforce, making agriculture a major sector in the country's economy (OECD, 2020[13]; OECD, 2021 [14]). At the same time, informal labour and subsistence producers represent a large share of the agricultural workforce (OECD, 2016[15]; OECD, 2021 [14]; Berk, $\left.201{ }_{[16]}\right)$. In $2016,81 \%$ of farms operated 10 hectares or less (TUIK, 2016[17]) and marketed only a small proportion of their output. ${ }^{3}$ As a consequence, natural hazards that affect primary agriculture, and at times the economy as a whole, may have an outsized impact on these vulnerable populations given their limited capacity to manage risk.

In terms of land use, about one-third of Turkey's land area is utilised for agriculture. Field crops, including cereals, ${ }^{4}$ cover about half of the agricultural land and grazing uses about one-third of agricultural land. Livestock farming is a major and growing activity for Turkey's agricultural sector (Yapp and Dewdney, $\left.2021_{[18]}\right)$. Crops, ${ }^{5}$ including cereals and other field and horticultural crops, accounted for $53 \%$ of the total value of agricultural output in 2017, and livestock production ${ }^{6}$ accounted for the remaining $47 \%$ (OECD, $\left.2020_{[13]}\right)$, however, the share of livestock in agricultural production is increasing.

Regional variations in agricultural production reflect Turkey's diverse climatic and geographic conditions, which allow the production of a wide variety of agricultural commodities. Cereals and livestock production are predominant in inland regions - in particular, wheat is produced in the Anatolian interior. Higher-value crops are typically grown in the coastal areas and the majority of fruit and vegetable production takes place in the Aegean, Marmara and Mediterranean regions; citrus and olive production mainly takes place in the Mediterranean region; and hazelnuts and walnuts are cultivated largely on the Black Sea coast (OECD, $\left.2011_{[19]}\right)$. Traditional livestock farms prevail in the northeast and east of the country, where high altitudes and low rainfall and temperatures inhibit crop production (OECD, 2016[15]). More recently, larger commercial cattle farms for milk and meat have located closer to market infrastructure and consumers, ${ }^{7}$ where they compete with urban uses for water.

The composition of agricultural production also reflects the mix of agricultural policies in place. Turkish agricultural policies encourage the production of specific commodities through border measures and output payments; sunflower, potatoes, cattle and cotton received the highest levels of output based support in the 2018-20 period, while input support is available for a wider array of commodities (OECD, 2021 [20]).

Given the country's semi-arid climate, water access is a major concern for many Turkish farmers, ${ }^{8}$ particularly those located in inland. Annual average rainfall in Turkey is $574 \mathrm{~mm}$ (1981-2010 average), which is below the average for OECD countries (OECD, 2019[21]). However, this average masks considerable variations in precipitation among regions and from year-to-year. In particular, semi-arid environments prevail over much of the central, southern, and south-eastern regions, which are most at risk from drought. As a result, water shortages can occur over large agricultural areas, causing yield fluctuations. In parts of central Anatolia, annual rainfall is $300 \mathrm{~mm}$, and droughts are expected more than once every four years. The combination of rainfall deficit and other climatic factors, especially high temperatures, creates a serious risk

\footnotetext{
${ }^{3}$ Although this share may be underestimated given the size of the informal sector.

${ }^{4}$ Cereals occupy around $25 \%$ of the cultivated area.

${ }^{5}$ Crop production includes cereals (wheat, barley and maize), other field crops (sugar beet, cotton, potatoes and tobacco) and horticultural crops (tomatoes, cucumbers, onions and watermelons, apples, citrus fruit, grapes, figs, hazelnuts, olives and tea).

${ }^{6}$ Animal production includes cattle, buffalo, poultry and eggs, sheep and goats and dairy products.

7 Stakeholder interview including with the World Bank Office in Ankara on 10 December 2019 and the Agriculture Committee of the TÜSIAD, Turkish Business Association on 12 December 2019.

8 Turkey is one of the eight water-scarce OECD countries covered in OECD's Agriculture and water policy changes (Gruère, Shigemitsu and Crawford, 2020[30]).
} 
of agricultural drought ${ }^{9}$ in the central and south-eastern parts of the country, where agriculture is the main economic sector (Komuscu, Erkan and Oz, 1998[22]).

Agriculture in Turkey is significantly affected by droughts - broadly defined as a temporary decrease of water availability in a given water system caused by prolonged deviations from average levels of precipitation (OECD, 2016 [23]). In particular, rain-fed crops suffer both directly through yields and output losses, and indirectly through increased risks of desertification and erosion. Droughts also affect the livestock sector's access to water and forage, causing yield losses and physiological stress, and forming conditions conducive to epidemic outbreaks of disease in livestock populations (CSB, 2018[4]).

The extent of drought impacts on the sector can be illustrated by the 2007-08 droughts, which severely affected 435000 farmers. Estimates of losses to the sector ranged from TRY 1.8 billion (USD 1.4 billion), as estimated by the Ministry of Agriculture and Forestry (MAF), to TRY 2.9 billion (USD 2.2 billion) as estimated by industry sources, accounting for expenses to minimise production impacts, such as by increasing irrigation expenditure (electricity as well as adjusting to deeper water levels). Overall, crop production declined by $9 \%$ year-on-year, with a drop in total cereal production of $16 \%$ (TUIK, 2020[24]), and as much as $90 \%$ for wheat and other grains in the south-eastern Anatolia Region and 60\% for red lentils (Engindeniz, 2013[25]). More recently, in 2020, most areas in Turkey faced severe drought, affecting both urban users' and agriculture's access to water. The year was the driest in five years after several seasons of below-average rainfall, which also affected the country's groundwater recharge. Consequently groundwater levels were in the lowest percentiles over the entire territory (NASA, 2021 [26]), and the State Meteorological Service (MGM) classified more than half of the country's territory as abnormally to exceptionally dry in 2020 (MGM, 2020[27]). Farmers in the Konya plain, a major cereals production area, experienced about $38 \%$ less precipitation from July to December 2020 compared to the same period in 2019 and the lack of rainfall dramatically reduced grain harvests (NASA, 2021[26]).

Agriculture is the country's largest water user. In 2016, the sector accounted for more than $85 \%$ of total freshwater abstractions, compared with an average of $42 \%$ across OECD countries (OECD, 2020[13]). Given the country's exposure to droughts and its high level of water use, water infrastructure, including dams and irrigation are critical for Turkey's agricultural sector. As such, policies emphasise irrigation as a means of increasing and stabilising farm output by attributing more than half of public expenditure for general services to agriculture to irrigation projects. In $2018,10 \%$ of agricultural land was irrigated (OECD, $2021_{[20]}$ ). Irrigation mostly utilises surface gravity, thus raising concerns about the efficiency of agricultural water use as only $3 \%$ of the irrigated area is equipped with the more efficient sprinkler and drip methods (FAO Investment Centre, 2016[28].${ }^{10} \mathrm{Illegal}$ groundwater abstractions for agricultural use is also a growing problem (OECD, $2021_{[29]}$ ), particularly in basins with water restrictions. Irrigation also faces feasibility issues, for example when a deeply entrenched river course makes it difficult for engineers to raise the water to the level of surrounding agricultural land.

Droughts that have occurred in the most recent decade (2009-19) have been particularly severe (OECD, 2021[29]; Gruère, Shigemitsu and Crawford, 2020[30]). This foreshadows the projected increase in the frequency and intensity of drought resulting from increased annual mean temperatures and changed precipitation patterns due to climate change. According to climate change modelling studies carried out by the General Directorate for Water Management (SYGM), the annual average temperature is expected to be between 2.0 and $5.9^{\circ} \mathrm{C}$ warmer in $2070-2100$ than in the reference period (1971-2000). Precipitation is projected to decrease by around $10 \%$ by the end of this century, although the extent will vary by region (CSB, 2018[4] $).{ }^{11}$ Importantly, most agricultural production areas - such as central Anatolia, which is a significant wheat production area for Turkey, as well as southeast Anatolia (cotton and cereals) - are predicted to suffer from more frequent and intense droughts in the future, and rising temperatures and increased water stress in regions away from coastal areas will place pressure on the production of water-intensive crops such as cotton and wheat (Climate Change Post, 2020[31]; CSB, 2010[32]; CSB, 2018[4]; Baglee et al., 2013[5]; FAO

\footnotetext{
${ }^{9}$ Agricultural drought refers to the impacts on agriculture by factors such as rainfall deficits, soil water deficits, reduced ground water, or reservoir levels needed for irrigation.

10 Traditional irrigation techniques rely on surface gravity systems (flood, furrow or basin) and cover about $97 \%$ of irrigated land.

11 While precipitation in southern and western areas is expected to decrease by more than $15 \%$, an increase of about $4 \%$ in the annual total precipitation is estimated in northern areas.
} 
Investment Centre, 2016 $[28]$; Tatar, 2016 $6_{[33]}$. Similarly, coastal areas including the Aegean (fruits trees, cotton and corn) and the Mediterranean (corn and citrus products) are also expected to have more severe droughts in the future.

In this context and given projected drier conditions, policies are needed that increase both preparedness for drought and support the transition of agricultural production towards more sustainable systems that relieve current and future water stress. However, improving the resilience of Turkey's agricultural sector to drought is complicated by the characteristics of the sector. Most prominently, a large share of the country's farmers are not integrated into modern value chains. A high degree of farm fragmentation poses a substantial challenge to farm infrastructure investments. Additionally, deep regional income disparities exist. This may be attributed to better jobs and higher earnings associated to manufacturing and services, which are mainly located in urban centres in the West, whereas agriculture prevails in other regions $\left(O E C D, 2018_{[34]}\right.$; OECD, $2019_{[21]}$; OECD, 2011 [19]; OECD, 2016 $\left.{ }_{[15]}\right)$. Finally, because of the country's generally low-skilled economy, this regional divide further hinders access to skilled labour in rural areas, obstructing the dissemination of technology and innovation (OECD, 2011[19]; Baglee et al., 2013[5]; OECD, 2016[15]; OECD, 2018[34]). The combination of these factors undermines farm productivity and resilience by limiting access to capital, services and knowledge (OECD, 2016[15]).

Turkey's agricultural sector must confront simultaneous challenges in its bid to become more resilient to drought and other natural hazards. On the one hand, improving the capacity of the country's farmers to produce and participate in markets through investment and development is considered a policy priority, including through support for new irrigation infrastructure and through farm programmes that encourage the production of strategic crops. On the other hand, there is a need to ensure that current investments and expenditures do not exacerbate future water stress conditions, and, instead, position the sector to be prepared for a drier future. Striking this balance between development and adaptation will be key to securing the sector's resilience to drought.

\section{Natural disaster risk management in Turkey}

Resilience to natural hazards is an outcome of measures put in place before, during and after an extreme event. Measures undertaken by governments, farmers and other stakeholders at each stage of the DRM cycle play a role in helping the agricultural sector reduce, absorb and recover from the impacts of natural hazards, and adapt and transform to increase resilience to future disaster risks. Measures may address specific or general risks as well as multiple, known and unknown, risks (OECD, 2020[2])

This section describes the measures in place in Turkey for managing risk and building resilience to natural hazard-induced disasters in agriculture. The first section describes the governance and key policy frameworks in place with a focus on those most relevant to drought. Subsequent sections review key policies and strategies - and how they contribute to building agricultural resilience - at each stage of the risk management cycle, beginning with efforts to identify, assess and raise awareness of natural hazard risks; followed by strategies to prevent or mitigate those risks; then measures that prepare for likely or imminent natural hazards; crisis management and disaster response efforts; and finally support to recovery and reconstruction.

\subsection{Governance frameworks affecting disaster risk management in agriculture}

Strong and effective governance arrangements are crucial for building agricultural resilience to natural hazard-induced disasters. Governance arrangements influence resilience through the relative emphasis they place on the different stages of the DRM cycle, and on the capacities to absorb the impacts of natural hazards versus adapt and transform in anticipation of future disaster risks in the agricultural sector (OECD, 2020[2]). Policy frameworks influence the decisions of central and local governments and agencies, farmers and other stakeholders by defining their roles and responsibilities in managing the risk of NHID, and by providing incentives to invest in disaster risk prevention, mitigation and post-disaster recovery (OECD, 2014[35]; UNISDR, 2015[10]). 
Agricultural risk management efforts relating to drought in Turkey are directed by several policy and governance frameworks, including disaster response plans, whole economy plans for economic development, agricultural policy frameworks (including specific sectoral plans for drought), and water governance frameworks. Disaster response in Turkey has been legislated since the late 1940s to cover large-scale, and mostly life-threatening critical risks, including floods, landslides, storms, droughts, wildfires and earthquakes (Unlu, Kapucu and Sahin, 2010[36]). Beginning in 2009, the country's emergency management command was consolidated into the Disaster and Emergency Management Presidency (AFAD). ${ }^{12}$ AFAD has primary authority for disaster risk reduction. It co-ordinates the preparation and implementation of disaster risk reduction plans, which include both ex ante measures to reduce disaster risks and disaster response, and ensures that risk reduction plans are aligned with the Sendai Framework's principles for disaster risk reduction. AFAD also centralises disaster prevention and damage minimisation activities, disaster response and interagency co-ordination (AFAD, 2019[37]).

Economy-wide development plans also affect natural hazard resilience. Specifically, increased resilience to climate risks is addressed by the country's Eleventh Five-Yearly Development Plan for the period 2019-23. The Plan identifies priority sectors for the economy and sets development targets for all sectors, including targets for increasing agricultural production. In addition, strengthening the capacity to adapt to climate change is one of the plan's priorities for the Environment (SBB, 2019 ${ }_{[38]}$ ). Of particular note related to the agricultural sector's capacity to manage drought, the Development Plan seeks to increase the agricultural area utilising pressurised irrigation systems, and to increase the overall irrigation rate (Table 1)..$^{13}$

Strengthening the agricultural sector's capacity to adapt to climate change is also a priority of Turkey's National Climate Change Action Plan (2011-2023). The action plan identifies three priorities for the agriculture sector. Specifically, agriculture is to a) increase its capacity to act as a carbon sink, including through increasing topsoil and subsoil biomass; b) limit its own greenhouse gas emissions; and c) develop a climate information infrastructure that will provide for the needs of the sector in adapting to and combating climate change (CSB, 2010[39]).

Additionally, policies carried out by the Ministry of Environment and Urbanisation (CSB), ${ }^{14}$ whose mandate includes environmental protection and territorial planning, can contribute to improved sector resilience. For example, CSB is active in the governance of several dimensions of resilience to earthquake and flood risks, most importantly prevention, preparedness and mitigation of environmental spill-overs, as well as guidelines for reconstruction.

Agricultural resilience is also directly affected by Turkey's agricultural policy framework, as administered by the Ministry of Agriculture and Forestry (MAF). The current agricultural policy framework places a strong emphasis on the production of specific commodities, through production-linked support including credit subsidies through the recent basin-based Strategic Crops Scheme (MAF, 2021 [40]). The scheme supports the production of specific crops, which are identified at the water basin level and centrally determined based on supply objectives. Other commodity-specific support measures include market price support through import tariffs and export subsidies. As a result of the combination of these policies, support to specific commodities accounts for over four-fifths of producer support (Figure 1). Additional schemes support the use of farm inputs, including credit and insurance, whereas on-farm investment receives limited support (2\%) (OECD, 2020[13]).

\footnotetext{
12 The AFAD was established by bringing together the Emergency Management (Prime Ministry), the Civil Defence (Ministry of Interior), and the Disaster Affairs (Ministry of Public Works and Settlement) (Law No. 5902). Currently, AFAD has 81 provincial branches across Turkey in addition to 11 search and rescue units.

${ }^{13}$ The irrigation rate is the calculated ratio of the area actually irrigated to the area equipped for irrigation.

14 The Ministry of Environment and Urbanisation (CSB) was instituted in 2011 by the merging of the Environment and the Public Works agencies. Its functions include urban planning, housing and construction regulations and environmental protection.
} 
Table 1. Policy targets for agriculture in the Eleventh Development Plan (2019-2023)

\begin{tabular}{l|r|r}
\hline \multicolumn{1}{|c|}{ Targets for the agricultural sector } & $\begin{array}{c}2018 \\
\text { actual }\end{array}$ & \multicolumn{1}{c}{$\begin{array}{c}\text { 2023 } \\
\text { target }\end{array}$} \\
\hline Land Consolidation Activity Area (Million hectares, cumulative) & 8.2 & 8.5 \\
\hline Land Consolidation Area for which Registration Procedures are Completed (Million hectares, cumulative) $^{1}$ & 3.6 & 6.2 \\
\hline Irrigated Net Agricultural Area (Million hectares, cumulative) & 3.3 & 5.3 \\
\hline Pressurised Irrigation System Installed Area (Thousand hectares, annual) & 40.0 & 200.0 \\
\hline Irrigation Rate (\%) & 64.0 & 68.0 \\
\hline Ratio of Agricultural Supports Provided from Central Government Budget to Agricultural Value Added (\%) & 6.8 & 7.2 \\
\hline Oil Seed Production (Million tonnes) & 4.0 & 5.4 \\
\hline Production Amount of Medicinal and Aromatic Plants (Thousand tonnes) & 700.0 & 1200.0 \\
\hline Ratio of Culture Breeds in Cattle Presence (\%) & 49.0 & 56.0 \\
\hline Red Meat Production Amount (Million tonnes) & 1.1 & 1.7 \\
\hline Pasture Reclamation and Management Area (Thousand hectares, cumulative) & 68.0 & 518.0 \\
\hline Ratio of Forest Areas to Country Area (\%) & 29.0 & 30.0 \\
\hline
\end{tabular}

Note: Data for 2018 is provided by the Ministry of Agriculture and Forestry, the General Directorate of State Hydraulic Works (DSI) and the General Directorate of Forestry.

1. Based on the activities of the Ministry of Agriculture and Forestry and DSI.

Source: Eleventh Development Plan, Strategy and Planning Presidency, 2019 (SBB, 2019[38])

\section{Figure 1. Level and composition of support to agriculture (2007-2019)}

As a percentage of gross farm receipts

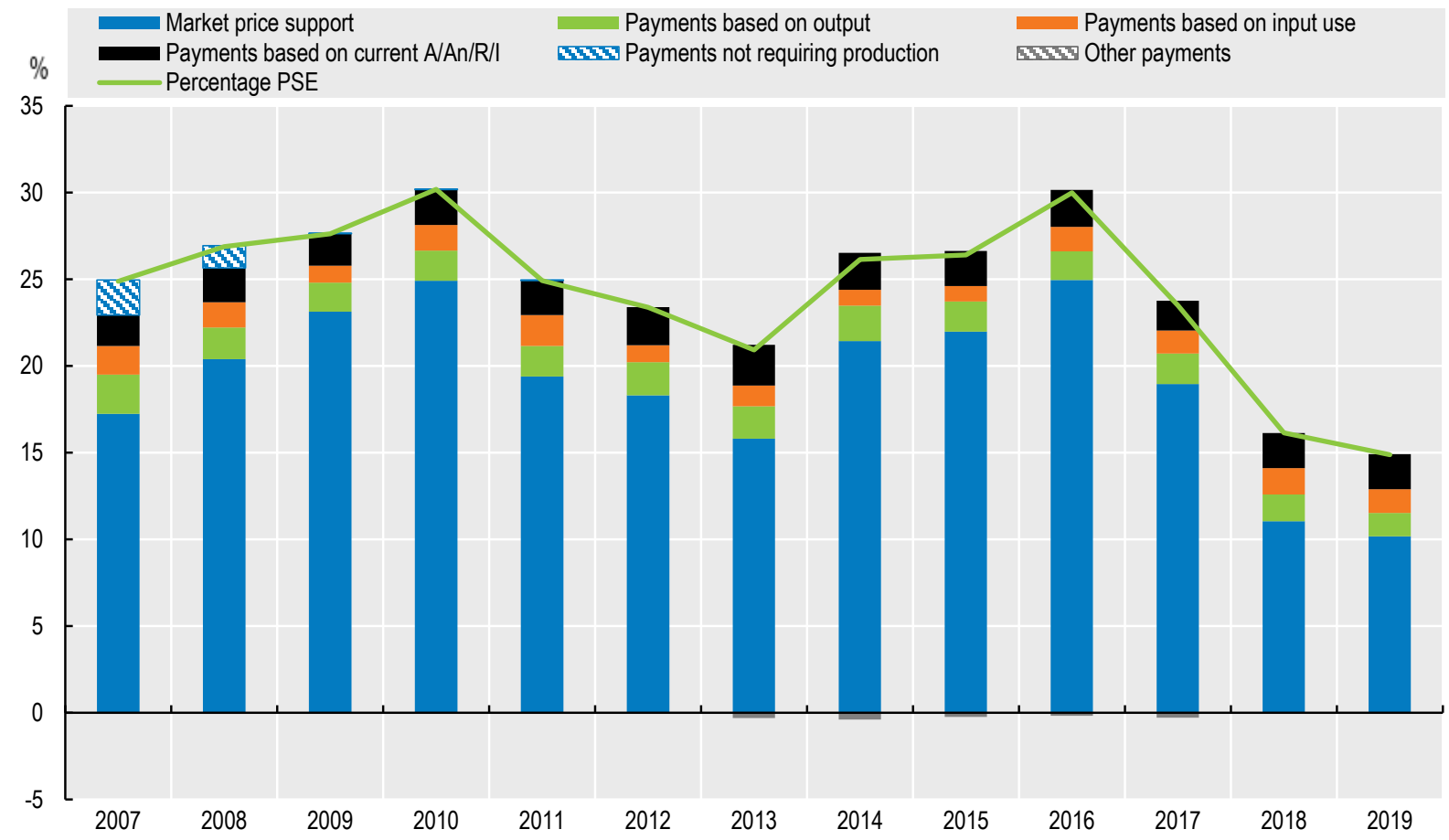

Note: A/An/R/l: Area planted/Animal numbers/Receipts/Income.

Source: OECD (2021), "Producer and Consumer Support Estimates", OECD Agriculture statistics (database),

http://dx.doi.org/10.1787/agr-pcse-data-en. 
MAF's functions and structure have evolved over time, in part to enable the implementation of legislation developed to address risks faced by the sector. The MAF is organised in General Directorates (GD), several of which have a prominent role in the governance of agricultural drought risk, including:

- The GD Agricultural Reform (TRGM) leads the implementation of the Strategy for Combatting Agricultural Drought and Action Plan (discussed below), and co-ordinates drought surveillance and the early warning chain of decision. TRGM is also the agricultural public interlocutor for the Agricultural Insurance Scheme (TARSIM).

- The GD Research (TAGEM) undertakes public agricultural research. Its priorities are identified in its master plan that identifies four axes for public research, including research on drought mitigation and adaptation. TAGEM operates a network of 48 Research Institutes. ${ }^{15}$

- The GD State Hydraulics Works (DSI) is Turkey's central public authority responsible for constructing and managing large-scale water infrastructure. The agency also monitors water levels in dams. The operation and maintenance of secondary and tertiary canals are gradually being decentralised and transferred to the Water Users Organisations (WUO) and more recently to municipalities.

- The Turkish State Meteorological Service (MGM) monitors and forecasts weather, including precipitation. ${ }^{16}$

- The GD Water Management (SYGM) is responsible for basin management, water quality, flood and drought management, related research, and the preparation of future water policy.

After the occurrence of a severe drought in 2007, the MAF introduced its Strategy for Combatting Agricultural Drought and Action Plan (the Drought Strategy hereafter) - a five-year, drought-specific governance framework that is renewed periodically. The Strategy's aims are to minimise the effects of droughts on agriculture by emphasising the improved and increased use of irrigation and water resources. It also prioritises risk assessment through the monitoring activities of the Agricultural Drought Management Coordination Board (TKYKK). ${ }^{17}$ It targets increased drought preparedness through research and development $(R \& D)$, extension and increased public awareness; drought mitigation through planning sustainable use of agricultural water; and drought response through long-term mitigation measures such as improving the sustainable supply of water and water demand management.

The Drought Strategy aims to improve policy co-ordination through increased participation of local governments and the provincial offices of ministries, as well as stakeholders such as farmers. Specifically, the Drought Strategy identifies roles and responsibilities for government agencies and engages with farmers and private sector stakeholders through consultations. Moreover, the Strategy is implemented at the provincial level through Provincial Agricultural Drought Action Plans established by Agricultural Drought Provincial Crisis Centers, which bring together local stakeholders under the lead of provincial governors. ${ }^{18}$ The action plans prioritise data collection and identify response measures that are to be implemented when an early warning is triggered (Box 2). Provincial action plans are also taken into consideration when Basin Level Drought Management Plans are prepared (discussed below). However, the action plans do not specify the roles or responsibilities of wider agricultural sector stakeholders in managing drought risk. More detailed information on the strategy and its contribution to resilience to drought is provided in relevant sections of the report.

\footnotetext{
15 TAGEM's network of 48 research institutes comprises 11 central, 10 regional and 27 subject-based centres.

16 In September 2020, the Department of Climate and Agricultural Meteorology was created in the MGM (MAF) to carry out climate change related $R \& D$ activities and contribute science on this issue.

17 The Board is co-ordinated by the Agricultural Insurance and Natural Disasters Department within TRGM and brings together MAF General Directorates, Water Users Organisations (WUO) that operate and manage the end-user segments of larger irrigation schemes, other stakeholders, as well as academia (TKYKK, 2013[48]).

18 Stakeholders include provincial representatives from relevant ministries and general directorates, the Provincial director of health, municipality representatives, academia, the president of the chamber of agriculture, irrigation, drinking water and producer unions, chairmen of co-operatives and representatives from other relevant non-governmental organisations.
} 
Water governance also plays a substantial role in managing drought risks. Water management in Turkey involves several public and not-for-profit institutions including several MAF GD (SYGM and DSI), as well as locally-based Water Users Organisations (WUO). ${ }^{19}$ At the national level, the National Water Plan (2019-23) is the first integrated approach to water management in Turkey (MAF, 2019[41]) with economic, social, cultural and environmental ambitions. The plan aims to safeguard the quality and quantity of water resources. Of specific relevance to agriculture, the plan prioritises water efficiency gains with wider use of pressurised irrigation, and the implementation of water allocation plans and so-called socio-economic pricing of water. The plan envisages enforcement instruments that are under construction, including a penalty and incentive system. Under the plan's priority for water quality, the control of the use of phyto-sanitary products will also affect agriculture. The National Water Plan is deployed at the river basin scale in each of Turkey's 25 river basins by involving relevant stakeholders in decisions about water resource management. However, information on the level of stakeholder participation is not available and the impacts of the plan are not clear.

As part of its activities, SYGM is developing a range of management plans for each of Turkey's 25 river basins: River Basin Water Management Plans, Drought Management Plans, Sectoral Water Allocation Plans and Flood Management Plans. To date, 15 Drought Management, 5 Sectoral Water Allocation Plans and 17 Flood Management have been completed and plans for the 25 basins are planned to be finalised by 2023.

The development of River Basin Management Plans, currently underway, relies on stakeholder participation to identify measures, at the river basin scale, that protect, improve and contribute to the sustainability of the water environment. ${ }^{20}$

The Drought Management Plans analyse the risks of the four types of droughts ${ }^{21}$ based on climatic and hydrologic studies to identify sectoral vulnerabilities. Provincial Agricultural Drought Action Plans are also considered when identifying drought prevention measures, and recovery and intervention measures to be implemented during and after drought.

The Sectoral Water Allocation Plans (SWAP), are established by SYGM and put forward by the Water Management Coordination Board to be published as Ministerial Circulars prior to their implementation on a yearly basis. The Allocation plans consider projection cycles ${ }^{22}$ to optimise water allocation based on hydrological, environmental, economic, sectoral and social conditions. The monitoring of the annual implementation of the SWAP is based on the estimated water potential for the upcoming water year that combine water availability information established by the DSI - Turkey's central water agency - and climate data supplied by MGM with projected climate conditions. ${ }^{23}$ The SWAP are notified to central and local agencies and municipalities, ${ }^{24}$ for implementation and end-year reporting to SYGM for evaluation.

\footnotetext{
19 Water User Organisations are established at local level and can take different legal forms including irrigation associations or irrigation co-operatives.

20 The River Basin Management Plans apply to surface freshwaters (including lakes, streams and rivers), groundwater, ecosystems such as some wetlands that depend on groundwater, estuaries and coastal waters out to one nautical mile https://ec.europa.eu/neighbourhood-enlargement/sites/near/files/pdf/turkey/ipa/2011/part2/tr2011.0327.21 river basin1402 2012-16 04 2012.pdf.
}

${ }^{21}$ The four types of drought can be defined as follows: 1) Meteorological drought happens when dry weather patterns dominate an area. 2) Hydrological drought occurs when low water supply becomes visible in streams, reservoirs and groundwater, usually after many months of meteorological drought. 3) Agricultural drought happens when crops are affected. 4) Socioeconomic drought happens when the supply and demand of various commodities, and communities consuming and producing those are affected (NOAA - NCEI, 2021 [79]).

22 The water year is from 1 October to 30 September.

${ }^{23}$ As part of the SWAP, scenarios are prepared that take into account sectoral development and the optimum water volumes that can be allocated to the sectors on the $1^{\text {st }}, 2^{\text {nd }}, 3^{\text {rd }}, 4^{\text {th }}, 5^{\text {th }}, 6^{\text {th }}, 12^{\text {th }}$ and $18^{\text {th }}$ year. Scenarios are at basin and sub-basin scale. Based on the results of the drought and climate change adaptation studies, the temporal and sectoral changes are determined by optimising water resources and water demands for the normal and four drought conditions in the basin and sub-basins.

${ }^{24}$ Stakeholders include the General Directorates (GD) of several ministries including GD of the MAF, of CSB, of the Ministry of Energy and Natural Resources and of the Ministry of Industry and Technology as well as the GD of Social Sectors and Coordination, GD of Public Health, the Energy Market Regulatory Authority, the GD of Energy Markets Operating I.C., GD of Electricity Production I.C Municipalities, Special Provincial Administrations and Water and waste water utilities. 
The SWAP are highly relevant to agriculture as they identify optimised crop patterns that would minimise the water deficit during drought periods and, at the same time, ensure the continuity of agricultural production and farm incomes. The crop patterns aim to contain the water deficit by identifying crops that consume less water than the existing basin production. MAF's General Directorate of Plant Production together with the Provincial Directorates of Agriculture and Forestry are responsible for the implementation of the crop pattern determined in the SWAP. While there is no obligation for producers to take-up the recommended crop pattern, a number of measures within the framework of the agricultural policy, encourage the substitution of existing crops with the optimal crops. Incentives include financial support, farmer training and technical support on the field that are carried out by the relevant MAF's General Directorates.

The Flood Management Plans are consistent with the EU Water Framework, and Floods Directives (EU, 2007 ${ }_{[42]}$; EU, 2000 $0_{[43]}$. The Plans include a preliminary flood risk assessment as well as a hazard and a risk map. Based on these elements, the plans identify precautions to be taken before, during and after floods in order to mitigate their negative effects on human health and life, environment, cultural heritage, property and economic activities.

Ground and surface water infrastructures are managed by the DSI. As such, DSI is responsible for constructing and maintaining irrigation and drainage infrastructure. While infrastructure management remains under DSI, the operation and maintenance of secondary and tertiary canals is gradually being decentralised and transferred to the Water Users Organisations (WUO) and, more recently, to municipalities

Figure 2. Disaster risk management governance and frameworks for agricultural droughts in Turkey

\begin{tabular}{|c|c|}
\hline $\begin{array}{c}\text { Ministry of Agriculture } \\
\text { and Forestry (MAF) }\end{array}$ & $\begin{array}{c}\text { Provincial Agricultural } \\
\text { Drought Action Plans }\end{array}$ \\
\hline Agricultural Reform (TRGM) & $\begin{array}{c}\text { Strategy for Combatting } \\
\text { Agricultural Drought } \\
\text { and Action Plan }\end{array}$ \\
\hline Hydraulics Works (DSI) & $\begin{array}{c}\text { Agricultural Insurance Scheme (TARSIM) } \\
\text { Public Compensation for Disaster Losses (Law 2090) }\end{array}$ \\
\hline Meteorological Service (MGM) & Agricultural weather monitoring and water projections \\
\hline Water Management (SYGM) & Rational Water Plan \\
\hline Research (TAGEM) & River Basin Water Management \\
\hline River Basin Drought Management Plans \\
\hline Ministry of Environment and Urbanisation (CSB)
\end{tabular}

Note: Activities related to data and information collection are in italic.

Source: Authors.

\subsection{Risk identification, assessment and awareness}

A shared understanding of natural disaster risks is important to encourage investments in natural disaster risk prevention, mitigation and preparedness by all stakeholders (OECD, 2020[2]). This can involve a range of activities, including vulnerability assessments; research into relevant phenomena; collection and analysis of data on the impacts of events and risk-reducing interventions; foresighting and horizon-scanning exercises; and strategies to raise risk awareness. Data collection and dissemination contribute to the sector's perception of their exposure to risks. The public sector undertakes many of these activities in Turkey. 
Risk assessment has been prioritised as an integral component of Turkey's Drought Strategy. Cross-sectoral drought vulnerability assessments are conducted under SYGM's river basin level Drought Management Plans (Section 3.1). As a result the awareness of drought risk is particularly high among agricultural agencies. Agricultural drought risk assessments are carried out by the Agricultural Drought Management Coordination Board (TKYKK) under TRGM. TKYKK has an established methodology for analysing and monitoring drought that is based on evidence collected by MGM and DSI. MGM contributes a nationwide monitoring of precipitation and analysis of their variability and trends at local, regional and national levels, which is available at monthly and water and agricultural year time scales ${ }^{25}$. MGM uses these observations to compute Standardised Precipitation Indices (SPI), Percent of Normal Indices (PNI) as well as Palmer Drought Severity Indices (WMO, 2012[44]) to classify the severity of droughts and trigger early warnings when appropriate. MGM's monthly short and long-term drought analyses are published together with drought maps on the Analysis page of the MGM website (MGM, 2021 ${ }_{[45]}$ ). In addition, DSl's precipitation records, which date from 1980, which are also used in TKYKK's agricultural drought risk assessments. ${ }^{26}$

Agricultural research institutions also contribute to drought risk identification, including through projects that use drought sensitivity modelling to determine drought vulnerability and to produce maps showing droughtsensitive locations. Such projects are carried out by TAGEM's Atatürk Soil and Water Agricultural Meteorology Research Institution, ${ }^{27}$ the International Agricultural Research and Training Center, ${ }^{28}$ and the Soil, Fertilizer and Water Resources Central Research Institute. ${ }^{29}$

There is a consensus at the government level that climate change affects the economy as a whole, and agriculture has been identified as the most sensitive sector. Within MGM, the Department of Climate and Agricultural Meteorology undertakes applied research on the impacts of climate change on agriculture in Turkey. The Department carries out research and development (R\&D) activities to analyse the effects on plant growth of drought and meteorological factors. The Department also contributes climate observations, studies, modelling and projections for local and international purposes, and provides scientific support to climate change adaptation and mitigation studies. The Department uses remote sensing and numerical forecast products, and contributes to the development of climatic and meteorological early warning systems related to weather and climatic events that adversely affect human, plant and animal health. At the same time, MGM is working to advance knowledge on the future of weather patterns and to forecast the evolution of the climate. As part of MGM's research, ${ }^{30}$ climate change projections and scenarios were computed in 2015, and these projections have since been revised (Demircan et al., 2017[46]). These projections serve as an input into climate change impact assessments and research foreseen by the Climate Change Action Plan, including research on agriculture. In one example, MGM's projections were used to analyse the effects of climate change on sunflower plant yields in Konya; other analyses have considered the impacts on crops such as wheat, sunflower, opium poppy, olive, apricot, and hazelnut (Gurkan et al., 2021 ${ }_{[47]}$ ). Foresight modelling exercises related to water availability, as well as local risk assessments are also carried out by SYGM as part of their watershed management activities. Notwithstanding, efforts to anticipate likely effects of climate change are scattered, and long term, whole-of-economy risk reduction action plans have not yet been developed (OECD, 2019 [21]).

Other initiatives have identified emerging risks that may pose a threat to the agricultural sector. The Climate Change Action Plan strengthens information systems to enable the sector's capacity to adapt to and mitigate the projected effects of climate change. The plan prioritises the improvement of information systems on areas of specific relevance to agriculture, including the preparation and dissemination of erosion risk maps; the monitoring of land degradation with the completion of a soil and land database and of a soil inventory; carbon content mapping and monitoring; land use and land use change database; water resources database

\footnotetext{
25 Turkey's water or hydrological year is from October to September.

${ }^{26}$ Further details on TKYKK's drought monitoring activities follow in Section 3.4.

${ }^{27}$ https://arastirma.tarimorman.gov.tr/kirklarelitopraksu/Sayfalar/EN/AnaSayfa.aspx.

${ }^{28}$ https://arastirma.tarimorman.gov.tr/izmirutaem/Sayfalar/EN/AnaSayfa.aspx.

29 https://arastirma.tarimorman.gov.tr/toprakgubre/Sayfalar/EN/AnaSayfa.aspx.

${ }^{30}$ It is expected that the establishment by MGM in 2020 of the Department of Climate and Agricultural Meteorology will strengthen the organisation's capacity to contribute scientific knowledge to the agricultural sector, as the MGM is a GD of the MAF.
} 
for assessing water quality and capacity; and agricultural yields monitoring (CSB, 2010 $\left.{ }_{[39]}\right)$. The plan also emphasises the promotion of sustainable agriculture techniques and soil management, including the role of the sector in protecting soil and water resources and sequestering carbon (CSB, 2010[39]). Specifically, desertification and erosion are emerging risks identified by the "Sustainable use of soil and water resources" axis of TAGEM's master plan, carried out at TAGEM's Soil, Water and Desertification Research Institute at Konya. Analysis of these risks - and plans to combat them - are the responsibility of MAF's General Directorate for Combating Desertification and Erosion (ÇEM). ÇEM's Desertification Model and ÇEM's Dynamic Erosion Model and Monitoring System (DEMIS) has quantified the amount of actual soil erosion at country scale, and also monitors changes to soil erosion. However, it is not clear how widely DEMIS outputs are disseminated and used by public and private sector stakeholders.

\section{Box 2. Risk identification and assessment in Turkey's Strategy for Combatting Agricultural Drought and Action Plan}

As part of the priorities set under the Drought Strategy, the Agricultural Drought Management Coordination Board (TKYKK) plays a key role in planning and implementing drought risk identification and assessment efforts.

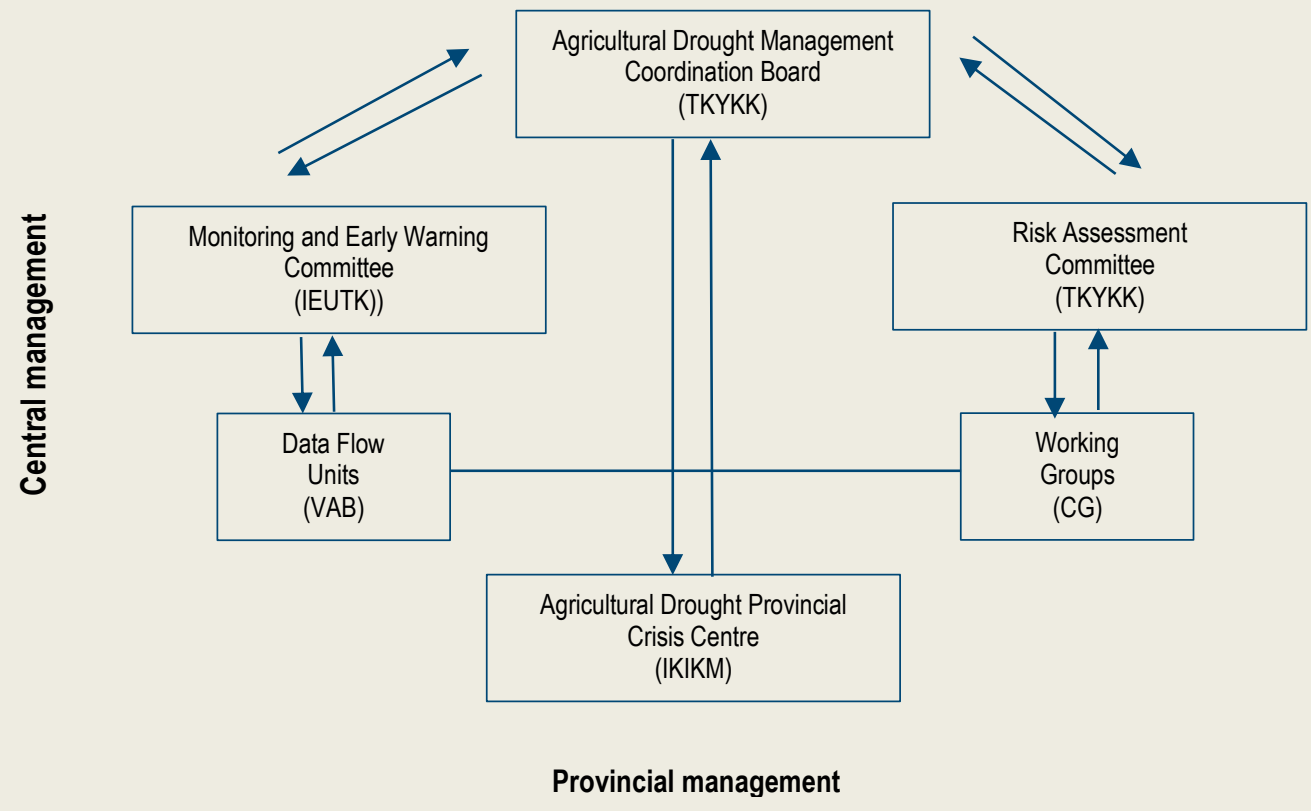

Drought monitoring: Drought monitoring is based on data developed by MGM, DSI and TAGEM, as well as Agricultural Drought Provincial Crisis Centers (hereafter Crisis Centres), and co-ordinated by the Data flow unit of the Board's Monitoring, Early Warning and Evaluation Committee (iEUTK). At its monthly meeting, iEUTK reviews evidence and data ${ }^{1}$ on water provision and needs, weather and regional phenological ${ }^{2}$ information. Based on the data, the Committee prepares a report.

Drought risk assessment: The report by the iEUTK is submitted to the Risk Assessment Committee (RDK), which is composed of experts from involved general directorates and stakeholders. The RDK considers three short-term (six months) projections for good, normal and bad scenarios prepared by MGM, and determines if an early warning for drought is required (TKYKK, 2013[48]). The MGM also computes standardised indicators ${ }^{3}$ that are based on the monitoring and analysis of precipitations and their variability. These indicators are used to classify the severity of droughts and trigger early warnings when appropriate. Drought risk monitoring is also enabled by DSl's long-term monitoring of precipitation data. For example, the analysis of the data by DSI has shown that since 1980, there have been 11 territory-wide drought years, while local droughts are observed in most years. 
Provincial data: Crisis Centres establish Provincial Agricultural Drought Action Plans that use drought scenarios based on local conditions to identify cropping patterns best adapted to dry and irrigated lands in dry periods. Since 2008, the Crisis Centres of all 81 provinces (iller) have established Provincial Action Plans. Crisis Centres also contribute provincial data to the monthly reports of the iEUTK.

Notes: 1. iEUTK data include water provision needs and supply capacity, including reservoir water levels, precipitations and weather forecasts and regional phenological data informing on seasonal biological activity of agricultural products cultivated in the province and associated water needs.

2. MGM's agricultural website offers phenological growth maps for 12 crops at http://www1.mgm.gov.tr/veridegerlendirme/fenolojik-normalharitalari.aspx.

3. Standardised indicators include the Standardized Precipitation Indices (SPI), the Percent of Normal Indices (PNI) as well as Palmer Drought Severity Indices (WMO, 2012[44])

Source: Based on information provided by the MAF and on National Drought Management Policies (TKYKK, 2013[48]).

The Turkish government's risk identification and assessment activities are also supported by international organisations such as the World Bank, which finances climate change research in Turkey, including by funding scenario analysis of rising temperatures, increased dryness by $2 \%$ to $5 \%$, as well as associated salinity issues and weed control needs. Another project funded by the World Bank analysed risks associated with climate change in the value chains for olive oil, fresh tomatoes, figs and ornamental plants in the Izmir region, one of Turkey's largest agricultural production regions. ${ }^{31}$ The Izmir region is identified as a climate change hot spot with a projected reduction of precipitation of up to $20 \%$, resulting in increased water scarcity and large impacts on agriculture and value chains (CSB, 2010[32]). Other examples of Turkey's participation in international research networks are described in Box 4.

The collection and assessment of data on economic disaster losses and damages is an identified good practice, as such data facilitate decision-making at both policy and farm levels (OECD, 2014[11]; OECD, 2020[2]). Turkey has several data repositories on agricultural damage and losses by NHIDs. First, TARSIM holds an inventory of insured events and their cost to individual farms. The data consist of a post disaster valuation of agricultural losses as well as damage information. Another source of damage and loss data is compiled by MAF's provincial directorates and communicated to TRGM as part of the ex post disaster compensation process for events that are not insured under TARSIM. Provincial Damage Determination Committees (DDC) centralise farm loss information. The data consist of the type and place of the adverse event, damaged equipment and land, and the monetary value of damage. The information is recorded in the loss and damage online repository of agricultural economic losses called AFET ${ }^{32}$ (Turkish word for disaster) managed by TRGM. In addition to these repositories, other information platforms record data on disasters. Since 2013 and in accordance with the Sendai Framework, AFAD's online Disaster Knowledge Bank $(\mathrm{TABB})^{33}$ has gathered information on disasters affecting all sectors (Box 3). Finally, DSI collects flood data through the TAMBIS application (Turkish acronym of "Flood, Failure and Response Information System"), which is available on the internet and mobile phones. The application can be used as a reporting tool for floods and infrastructure failures. The application also serves as a repository database for information on past occurrences of floods.

While Turkey has systems in place to record data on farm damages and losses by natural hazards, currently their use is limited to policy makers - for loss compensation support - or to TARSIM - for insurance payouts - and are not available to private sector stakeholders more broadly. Nonetheless, these information systems represent on-going efforts that Turkey can build on to create a public database for disaster loss and damage.

\footnotetext{
${ }^{31}$ Interview with the World Bank office in Ankara, 10 December 2019.

${ }^{32}$ http://tvk.tarim.gov.tr/afet.

${ }^{33}$ https://tabb.afad.gov.tr/.
} 


\section{Box 3. Turkey's Disaster Knowledge Bank (TABB)}

The Turkey Disaster Knowledge Bank (TABB) ${ }^{1}$ is an online platform under the authority of AFAD, and developed and managed by the Middle East Technical University (METU). TABB provides harmonised evidence on natural and human-induced disaster events going back to 1900 and is available to the public. TABB features an analysis module where individual events are recorded and a library module where disaster-related resources are stored in electronic form (books and periodicals, reports, audio and visual documents), or their location references, for example library or administration, if they only exist in physical format. Input to TABB is a password secured, ongoing collaborative process that relies on identified contributors.

Disaster events recorded in the analysis module in TABB are identified using the unique internationally harmonised GLobal IDEntifier (GLIDE) number ${ }^{2}$ facilitating information collection and comparison across sources. Overall, the module associates each event with 46 information dimensions, including the event type, its start date and location, numbers of human casualties and evacuations conducted, numbers of damaged construction and damage severity, agricultural areas affected, cattle losses, and total cost estimates. Recorded disaster events can be visualised in tabular form as well as maps.

While TABB has the potential to provide extensive information on each disaster event, it is not yet filled in a manner that provides consistent and reliable information on disaster losses and damage in agriculture. For example, while dates and locations of registered events are always listed, information on losses and damage in agriculture - for example, the agricultural area affected or cattle losses - are often missing. Furthermore, the monetary values of corresponding impacts are not provided, even though such information is valuable for decision making both on farm and at the policy level, in order to understand the impacts of disasters and target prevention and mitigation efforts to areas most in need.

In the absence of economic information, a simple count of agricultural events registered in the TABB database highlights a relatively high frequency of water-related events - mostly floods and droughts. In a context where the intensity of water-related extreme events is projected to increase in Turkey, it is likely that these hazards cause the greatest agricultural losses on average.

Notes: 1. A short presentation on TABB can be found in http://www.iiees.ac.ir/fa/wp-content/uploads/2016/04/00019-RL.pdf.

2. More information on the GLobal IDEntifier number can be found in http://www.glidenumber.net/.

\subsection{Risk prevention and mitigation}

Once risks have been identified and stakeholders informed, actions can be planned to prevent the risk that natural hazards result in disasters, and to mitigate their effects. These actions can stem from public-sector investments or activities, but private initiatives and farm-level activities are also critical. Public sector actors must also ensure that appropriate policy incentives are in place to encourage private investments in risk prevention and mitigation.

Recent multi-hazard risk reduction plans developed by AFAD, both at the national and provincial levels, raise awareness of the need for investments in risk prevention and mitigation by encouraging stakeholder to participate in their development. The first provincial Disaster Risk Reduction Plan (IRAP) was developed by mobilising technical experts and stakeholders through information meetings and workshops, and was completed in July 2020. The Plan, prepared for the Kahramanmaraş Province, prioritises investment in risk mitigation and prevention, such as the demolition of dangerous buildings, and aims to improve co-ordination between central and local government on disaster risk management by establishing a network of institutions with primary or secondary responsibility to implement actions identified in the plan over the 2020-25 period. The plan prioritises the protection of lives and properties and, while earthquakes are identified as the top hazard, it also addresses the effects of climate change on floods and excessive heat. ${ }^{34}$ The publication of

\footnotetext{
${ }^{34}$ https://en.afad.gov.tr/turkeys-first-provincial-disaster-risk-plan-introduced-to-the-public.
} 
the national level Disaster Risk Reduction Plan (TARAP) is pending while six other IRAPs are planned for publication in 2021.

Drought risk prevention and mitigation measures in Turkey include a variety of activities, ranging from the development of water-related infrastructure to activities targeting longer-term adaptation to a drier climate, as well as risk management tools to help farmers mitigate the impacts of water shortage.

Surface and groundwater infrastructures are managed by the DSI, Turkey's central water agency. As such, DSI is responsible for constructing and maintaining irrigation and drainage infrastructure. This includes largescale infrastructure works, such as inter-basin water transfer infrastructure to move water to areas in need when droughts are localised. While infrastructure management remains under DSI, the operation and maintenance of secondary and tertiary canals is gradually being decentralised and transferred to the Water Users Organisations (WUO) and, more recently, to municipalities. ${ }^{35}$ Most WUO are not-for-profit institutions. As of October 2020, 183 WUO operated 1462 irrigation facilities serving an area of 2.3 million hectares and 756359 water users, of which $57 \%$ were members of a WUO. In effect, the WUO fully control the management and operations of all secondary and tertiary irrigation canals, up to the end users (DSI, 2020[49]). WUOs collect irrigation fees that are intended to cover the costs of operation, day-to-day maintenance and administration of irrigation networks. In addition, farmers themselves also supply water to their farmlands independently either directly from surface water flowing to it, or from groundwater wells. According to DSI, about $80 \%$ of groundwater wells are informal (IBRD, 2016[50]).

The development of water infrastructure, mainly as a means of hydropower production, has been a longstanding economy-wide objective, with substantial implications for the agricultural sector. The government's emphasis has been to reap the associated benefits and increase agriculture's access to irrigation, to enable productivity growth and improve the sector's resilience to variations in precipitation. The reservoirs offer a means to regulate access to water when precipitation levels vary, whereas drought conditions remain a direct challenge for irrigation. In $2018,10 \%$ of agricultural land is irrigated and the development of new irrigation infrastructure has been supported for many years with the objective of expanding the irrigated area. ${ }^{36}$ More recently, projects are carried out to establish underground water basins and dams, and limit expected water evaporation under the effects of climate change.

However, around one third of Turkey's irrigation network is older than 40 years, and the country faces a rapidly growing repair and renewal challenge and corresponding investment requirements (Kibaroglu, $\left.2020_{[51]}\right)$. Turkey has prioritised the repair and renewal of ageing irrigation infrastructure, which can limit water losses and generate water savings. Turkey also aims to modernise irrigation systems by transitioning to water saving irrigation systems. In 2013, DSI initiated works to upgrade irrigation infrastructures. Open canals, that are not suitable for direct installation of drip or sprinkler systems, are being gradually replaced by pressurised piped irrigation systems and centralised water measuring instruments are being installed (CSB, 2010[39]). In 2019, 39\% of DSI infrastructure was piped, which supports the adoption of sprinkler and drip irrigation, and also water metering. When expanded to larger areas, pressurised pipes may contribute to the diffusion of water-saving irrigation methods (Özerol, Bressers and Coenen, 2012[52]). DSI supervises and pays the cost of all rehabilitation programmes, which the WUO are expected to repay gradually. ${ }^{37}$ However DSI has continued to bear the costs as, to date, WUO have not repaid the costs of any structural maintenance and rehabilitation, pointing to governance and capacity gaps resulting from the transition from full infrastructure management by DSI to a system where segments of the infrastructure are managed by WUO. Rehabilitation projects for existing irrigation channels are also supported with World Bank loans in four selected areas, and are conditional upon integrated basin management as part of a river basin strategy.

\footnotetext{
35 The transfer process, started in 1953, aims to improve fee recovery, operational efficiency and equity in water access, while at the same time, centring the role of government, and its expenditure, on the provision of infrastructure. The transfer process has progressed, requiring a number of amendments to the Irrigation Law, and not all objectives are achieved yet. Recent changes have increased the influence of public administration in the governance of WUO; civil servants are nominated to chair WUO, and WUO may be abolished upon government decision (Kibaroglu, 2020[51]).

36 The Eleventh Development Plan aims to expand the irrigation capacity by 2 million hectares by investing USD 1.3 billion annually.

${ }^{37}$ Smaller projects that cost less than TRL 5 million (USD 700 000) can be carried out fully by either DSI or by WUOs with DSI machinery and equipment. The reimbursement period extends between 5 to 10 years and is extended to 15 years for larger projects
} 
Water efficient systems such as drip irrigation and sprinklers are effective and affordable methods to economise water use. But these systems only accounted for $22 \%$ and $17 \%$ of Turkey's irrigation systems respectively in 2019 , despite the fact that government investments prioritise subsidies for farmers to install drip irrigation rather than the renewal of aging infrastructure.

Research shows that investments in more efficient water infrastructure alone are likely to lead to increasing demand for water resources, unless accompanied by a strong water allocation and enforcement programme (Grafton et al., 2018[53]; OECD, 2016 [23]). Turkey has developed Sectoral Water Allocation Plans for five river basins, which propose actions for public institutions, including DSI and MGM in both normal and drought conditions. Water allocation are based on sectoral demand and expressed water needs, and optimisation modelling is used for attribution between competing uses for drinking water, agriculture, tourism, industry and energy, and aquatic systems ecosystem maintenance. However, as there is no accounting of farmers' water use in the absence of meters, agricultural needs are estimated based on crop cover area and crop water needs. Given this uncertainty surrounding actual water withdrawals, there does not seem to be a means of ensuring that water allocations are respected. Ultimately, the allocations are indicative and no enforcement mechanisms are foreseen.

$R \& D$ efforts to alleviate pressure on water resources and to enhance the sustainable management of water are also relevant for mitigating the impacts of droughts. Such work is undertaken by the Turkish Water Institute (SUEN), a consultative body of the MAF that provides science-based advice to support planning and formulation of water policies and strategies. SUEN's broad objectives include combatting climate change, and preserving and improving the quality and quantity of water and soil resources. Reflecting this, SUEN's activities include advice on water governance issues and capacity building services, as well as research on current and projected water resources, including modelling on transboundary water basins. Training activities support institutional capacity building on water and wastewater management issues, including river basin planning and groundwater management, which are of specific relevance to agricultural droughts. Research carried out at SUEN also includes exploring novel water sources, including so-called unconventional water sources. In this vein, a water re-use pilot project is underway in Konya as part of a multi-locations test (PRIMA, 2019[54]). Water re-use and other novel water sources are also explored by DSI, including the use of wastewater. While first results confirm feasibility, treatment issues must be solved before use of wastewater can be safely exploited in agriculture.

As much of Turkey's territory is semi-arid and conditions are forecast to become even drier over the coming decades, an important component of drought prevention and mitigation is research into strategies and measures that support adaptation and will reduce the agricultural sector's vulnerability to future droughts. Several objectives identified by the Climate Change Action Plan have the potential to serve the sector's adaptive capacity and its contribution to climate change mitigation. In particular, in addition to the sector's contribution to water and soil biomass management, the government's objectives include research and data collection to support effective crop, soil and water management (CSB, 2010 ${ }_{[39]}$ ). Research to develop plant and animal species that are tolerant to heat, drought, diseases and pests is a priority of the National Strategy on Climate Change (CSB, 2010[32]). Research also explores the improved use of irrigation with TAGEM's national research project on water-saving irrigation methods in limited water conditions.

TAGEM's Bahri Dağdaş International Agricultural Research Institute (BDIARI), which is located in the Konya area, ${ }^{38}$ specialises in plant and animal genetic resources, gene discovery and breeding programmes, with a particular focus on drought resistant varieties and exploring the biodiversity of Turkey's wealth of plant species representation. ${ }^{39}$ BDIARI projects include breeding plants and animals and the determination of genetic traits of tolerance to droughts and high temperatures. BDIARl's inventory of wheat landrace biodiversity, carried out over the period 2009-14, documents important agronomic traits and identifies welladapted local wheat landraces, with the aim of selecting certain characteristics such as drought and high

\footnotetext{
38 The location of the BDIARI at Konya is opportune for drought research. As described by Berktay and Nas: "The Konya Closed Basin (KCB) is Turkey's 4th biggest basin according to its precipitation area [...] Disruption of the natural hydrological regimes and over-consumption of freshwater resources pose the principal threats to the wetlands, salt lakes and freshwater bodies. Irrigation schemes have diverted water from the streams that feed scattered freshwater resources to convert some of the salty steppes to agricultural fields." (Berktay and Nas, 2008[74]).
}

${ }^{39}$ Over $30 \%$ of the 9000 species found in the country are endemic to Turkey (FAO, 2018 $\left.[77]\right)$. 
temperature tolerance. ${ }^{40} \mathrm{In}$ the field of husbandry research, BDIARI animal science applications include the dissemination of local and imported breeds as well as on-site analysis of the characteristics of native sheep and goat breeds, to identify genetic traits that enhance tolerance to drought and heat conditions, in support of climate change adaptation. BDIARI also collaborates in international research projects, and with the private sector. BDIARI's contribution in this area is mainly in the development and exchange of wheat genetic resources (for a more detailed description of Turkey's participation in research networks, see Box 4).

After new varieties are developed, BDIARI facilitates their adoption by providing extension services and farmer field schools that disseminate drought resilient farming practices, among other activities. Farmer field schools rely on experimentation and peer learning to facilitate the uptake of innovative farming practices, including conservation tillage practices such as no-till and strip-till that can help to conserve soil moisture. More generally, TAGEM's extension service extends research results to farms and facilitate innovation takeup. Extension services also contribute to raising farmers' awareness on the effects of climate change. Training related to drought management includes knowledge dissemination of water harvesting techniques, soil conservation and moisture monitoring. Extension services also focus on specific target groups, such as the WUO, to serve as intermediaries for the dissemination of knowledge on water use efficiency issues.

\section{Box 4. Turkey's participation in international research networks and research collaboration relating to drought mitigation and prevention}

The General Directorate Agricultural Research and Policies (TAGEM) of the MAF contributes research to the Strategy for Combatting Agricultural Drought and Action Plans. TAGEM research centres engage in international research networks, including by participating in regional or thematic co-operation and projects. The benefits of international research co-operation are numerous. Projects mutualise and strengthen research capacity, improve access to research outputs and accelerate the dissemination of knowledge and results. They ease access to funds and mobilise individual expertise of each institution to generate knowledge that can be widely disseminated.

Turkey is a member of the Consultative Group on International Agricultural Research (CGIAR) and its research centres, specifically the International Maize and Wheat Improvement Center (CIMMYT) and the International Centre for Agricultural Research in the Dry Areas (ICARDA). For example, the International Winter Wheat Improvement Program (IWWIP) was a joint programme between the MAF, CIMMYT and ICARDA to develop and facilitate exchange of wheat germplasm for breeding purposes (Keser et al., 2017[55]). Turkey is also a signatory to the International Treaty on Plant Genetic Resources for Food and Agriculture (FAO, 2009[56]). BDIARI's Drought Phenotyping Centre is also a member of the CGIAR's International Plant Phenotyping Network. It contributes scientific research to the sector's adaptation to a drier climate.

Examples of research collaboration include the inventory of wheat landraces developed with the IWWIP; a soil database repository of more than 50000 soil samples (of $30 \mathrm{~cm}$ depth) that feeds into the Global Soil Partnership of the Food and Agricultural Organization (FAO, 2021[57]); and research on drought tolerant plants with ICARDA. Another project, part of the European Joint Programme on agricultural soil management, aims to develop a reference framework on climate smart sustainable agricultural soil management (EU, 2019[58]).

The Turkish Water Institute (SUEN) also engages in international research networks and initiatives. An example of a drought relevant collaboration is the Watermed 4.0, which explores smart technologies for agricultural irrigation in semi-arid areas. SUEN's participation in the OECD water governance initiative is another example where SUEN facilitates the dissemination of the OECD Principles on water governance (OECD, 2015[59]).

\footnotetext{
40 The results of a survey of farmer perceptions carried out as part of the inventory confirms landraces are replaced by commercial - higher yield -varieties and notes that landrace farming takes place at locations that are more distant from markets (Khan et al., 2016[75]).
} 
Turkey's research institutions also benefit from technical co-operation with International Organisations. Projects aim to strengthen climate change resilience including testing farming practices that increase drought resistance through soil management. As part of this collaboration with the FAO (with funding from the International Fund for Agricultural Development (IFAD)) BDIARI is undertaking a project on sustainable land management and efficient use of water resources. The project has several dimensions, including farmer training and peer learning on no-tillage practices. The project is deployed through a field pilot where a lead farmer establishes a demonstration no tillage plot and a control plot. The technique is tested with sunflower, maize, beans, wheat and barley. It also mobilises farm networks and peer learning which have proved to be efficient ways for the dissemination of farming practice change.

Several projects support water use savings and efficiency gains. A World Bank-funded project directed towards WUO supports efficiency gains of irrigation models by emphasising a water basin approach. Stakeholder awareness is increased through workshops with the participation of producer unions, district offices and chambers of industry (World Bank, 2019[60]). Another project that aims to facilitate the take up of IT enabled precision irrigation is also underway. A programmed approach to drip irrigation is carried out with the Seljuk University in 39 locations using precision agriculture to identify water needs for sugar and maize based on soil samples and weather patterns. In a second phase, the project will extend to apple orchards in 11 locations. Other ongoing research activities include a project funded by the Global Environmental Facility (GEF) to field test subsurface irrigation systems.

Notes: Besides its co-operation with the OECD, the SUEN also co-operates with the Organization of Islamic Cooperation (OIC), the Blue Peace Initiative in the Middle East, the Developing Eight Countries (D-8), the United Nations Economic Commission for Europe (UNECE, the International Water Resources Association (IWRA), the European Environment Agency (EEA), the International Water Association (IWA), the Union for the Mediterranean Task Force on Water- Employment-, Migration, the Global Wastewater Initiative (GW2I), the UN-Habitat GWOPA, Water JPI, and the World Water Council (WWC).

While public sector activities to prevent or mitigate drought mainly focus on improving water infrastructure and on research activities to facilitate adaptation to drier conditions, support is also available to the farmlevel uptake of insurance as a means to mitigate the financial impacts of natural hazards, including drought, on farmers. Turkey offers a variety of insurance products to prepare for the financial impacts of NHID events. Increased insurance coverage is also prioritised as a means to confine public expenditure on general disaster assistance by sharing damage cost coverage and, ultimately, increase the predictability of spending. Accordingly, the Turkish Catastrophe Insurance Pool (DASK) aims to offer generalised household property earthquake insurance through a compulsory scheme following international examples from the Earthquake Commission (EQC) in New Zealand ${ }^{41}$ and California's Earthquake Country Alliance (ECA), ${ }^{42}$ and, at the same time, to limit public expenditure on earthquake damage compensation. DASK was established in 2000, after the İmit earthquake of 1999 that caused over 17000 fatalities, extensive damage to buildings and infrastructure, and resulted in damages estimated between USD 12 billion to USD 25 billion (Turkish Red Crescent, 2006 $[61])$. The Pool is a public-private partnership, operated by multiple private insurance companies. Risk is transferred partly to the international reinsurance market and government support under so called "excess of loss support" covers TARSIM activities that cannot be reinsured (GFDRR, 2011 [62]; Gurenko et al., 2006[63]).

DASK activities encompass re-insurance for the domestic insurance market and, since a Cabinet decree of 2015, guarantees the agricultural insurance pool (TARSIM) (TCIP, 2016[64]). TARSIM was set up in 2006 to improve farmers' access to insurance ${ }^{43}$ and is based on voluntary participation. TARSIM is open to all farmers - although participation is conditional on registering with the MAF - and offers uniform insurance

\footnotetext{
${ }^{41}$ https://www.eqc.govt.nzl.

42 https://www.earthquakecountry.org/.

43 In 2005, the agriculture insurance Law No. 5363 was adopted to replace the private insurance system that had been in place since the late 1950s and had achieved little penetration (TARSIM, 2005[80]). Participating insurance companies contribute equal shares to the pool while they issue insurance policies in their own name. Risks and premiums are transferred in total to the pool. Insurance activities under TARSIM are managed by a not-for-profit company and directed by a Board where the Ministry of Treasury and Finance, MAF, the association of insurance and reinsurance companies, the Agricultural Chamber and TARSIM are represented.
} 
policies. Uptake is encouraged through a $50 \%$ to $67 \%$ premium subsidy, depending on the scheme ${ }^{44}$, paid directly by the government to the insurance pool. TARSIM has grown from 218000 policy subscriptions insuring TRY 1.5 billion (USD 1.2 billion) in 2007 to reach 1.8 million subscriptions in 2018, insuring a total of TRY 42 billion (USD 8 billion). It received TRY 2.4 billion (USD 423 million) in premiums in 2019 (of which $52 \%$ was subsidised) and paid TRY 1.1 billion (USD 227 million) in indemnities (TARSIM, multiple[65]). On the basis of agricultural land, penetration rates have reached $23 \%$ and are growing.

TARSIM currently offers eight insurance schemes for farmers. ${ }^{45}$ The main scheme under TARSIM is the crop insurance scheme, ${ }^{46}$ which provides coverage for hail, storm, whirlwind, fire, landslide, flood and earthquake, but excludes drought. In 2019, the crop insurance scheme accounted for more than $91 \%$ of all subscribed policies, $62 \%$ of premia and around $65 \%$ of compensations paid. Among crops insured, the largest coverage was for wheat, which represented nearly a quarter of the sums insured (TARSIM, 2020[66]). Selected crops, their stems and certified seeds may optionally be covered with an additional premium. ${ }^{47}$

Losses caused by drought are covered by the district-based drought yield insurance scheme developed in collaboration with BDIARI, whose extension services also facilitate farmers' adoption of insurance (TARSIM, $2020_{[67]}$ ). It was first offered to wheat growers in dry areas in 2017 , and subsequently extended to barley, oats, rye, triticale, chickpea and green/red lentil, and growers of certified seeds of these crops that are cultivated in dry farming areas registered to the Farmers Registry System (FRS). ${ }^{48}$ While it is labelled as drought insurance, the scheme offers an area-based multi-peril insurance product, which also covers damages from frost, hot wind, heat waves, excessive humidity and excess precipitation. The drought yield insurance is district-based and triggers when yields are below $70 \%$ of district average yield, with the gap paid to farmers. The drought yield insurance system is IT-GIS enabled. The technology uses the mapping

44 The subsidy covers $50 \%$ of the insurance premium in all branches, $60 \%$ of the insurance premium for the districtbased drought yield insurance and $67 \%$ of the insurance premium for frost risk coverage for fruits grown in open areas.

The second support provided by the state is "government excess of loss support". Reinsurance is obtained from the national and international insurance market in order to transfer the risks undertaken by TARSIM. Excess loss of support provides by the State for parts that cannot be reinsured.

"Government excess of loss support" is the undertaking by the State for the part to be determined by the President in the event that the protection (Reinsurance) provided from national and international markets is not sufficient. In extraordinary situations and in cases of more damage than expected, it is possible to compensate the damages by transferring the amount of additional allowance needed by the State to the Pool as "excess of loss support". In this context, "excess of loss support" is not a type of direct support given to producers, but a type of support provided by the government's agricultural insurance system when financially needed.

It has no relation with the aids made within the scope of the "Law No. 2090 on Aid to Farmers Suffered by Natural Disasters".

45 TARSIM currently offers eight insurance schemes: 1. District drought based yield insurance. 2. Crop insurance covers quantity losses due to hail, storm whirlwind, fire, earthquake, landslide and flood and quality losses of fresh fruits/vegetables and cut flowers due to hail. 3. Greenhouse insurance covers buildings, equipment and crops for losses due to hail, storm, landslide, flood, whirlwind, fire, earthquake, vehicle impact, snow and hail weight. 4. Cattle insurance covers registered breeding, dairy and male fattening cattle and buffalos for death and compulsory culling resulting from diseases, accidents, natural disasters and fires. 5. The same risks can be insured under the Sheep and goats insurance. 6. Poultry insurance, available for registered poultry raised in closed-sheds in conformity with bio-safety and hygiene rules. 7. Aquaculture and 8 . Beehives.

${ }^{46}$ Crop insurance under TARSIM covers the following events: a) Quantity loss due to hail, storm whirlwind, fire, earthquake, landslide and flood. b) Quality loss of fresh fruits/vegetables and cut flowers due to hail. c) Quantity loss of field crops, vegetables, strawberry and saplings due to wild boar attack. d)Quantity loss caused by the birds eating the seeds available on the table during the ripening and harvesting period for the Sunflower (For Oil), Sunflower (For Snack) crops and Sunflower (For Certified Seed) crop. e) Quantity loss caused by the rain risk for the opened bolls during the period from the opening of the bolls on the Cotton and Cotton (For Certified Seed) crop until the harvest. Other risks may be insured by holders of the above subscription on an optional basis.

47 The insurance is available to crop stems and certified seeds of wheat, barley, oat, rye and triticale.

48 Analysis of the evolution of insurance take-up by field crops growers in Illinois shows the positive effect of conditionality of support to insurance take-up. The analysis also suggests farmers' preference for revenue protection rather than yield insurance (Schnitkey, 2020[78]). 
of soil groups by the MAF and an evaluation of fertility indexes to determine reference parcels, subject to experts' confirmation. The technology also matches information from the agricultural land registry and uses satellite imaging for yields estimates. Participation in the scheme is conditional on the use of certified seed produced and distributed by BDIARI. All crops and geographic locations can be insured and there are no exclusions based on dry area farming.

While incentives exist to undertake on-farm prevention and mitigation activities their impacts are not monitored and farm level uptake of prevention and mitigation activities seems uneven. Many Turkish farmers continue to employ traditional farming practices adapted to semi-arid areas, such as mixed-cropping, cropping local landraces, and crop rotation and fallow, which may reduce the vulnerability of output under drought conditions. Outside of utilising traditional farming practices, sector stakeholders report that when producers receive warning indications of drought, they do take action to mitigate impacts, largely through the application of irrigation. When warnings are not generated, however, widespread losses have been observed, underscoring the vital role that early warning systems (see 3.4. Risk preparedness) play in drought risk management. ${ }^{49}$

Farm level capacity to manage risk influences the impact of natural hazards on the sector. The provision of extension services is critical for transitioning sustainable productivity growth in this regard. Extension services are provided through the geographically decentralised network of research institutes. In relation to droughts, they support the dissemination of water saving farming practices and the adoption of drought tolerant, quick maturing and drought resistant crops. Available data does not permit to document farmers' access to extension services, penetration levels or outcomes of extension.

\subsection{Risk preparedness}

Ensuring that the sector is prepared for adverse events includes a variety of activities carried out by the public sector (including contingency planning and risk monitoring), as well as efforts by farmers to adapt their operations in the face of emerging risks. The public sector also plays a role in knowledge generation through research activities and knowledge dissemination through education, extension and advisory services that strengthen the sector's capacity to manage crises effectively, minimise the disruptions through response mechanisms and ensure a quicker and more resilient recovery (UNISDR, 2015[10]).

Preparedness for drought in Turkey is enhanced through established monitoring programmes that inform all stakeholders about developing risks. These include watershed monitoring, drought monitoring, flood monitoring and monitoring of weather and other risks. Watershed monitoring with respect to drought is carried out by SYGM (described in Section 3.2).

Information on expected demand for, and the availability of, irrigation water contributes to drought preparedness. Ahead of the irrigation season, DSI's General Irrigation Planning Directorate collects estimates of irrigation water needs through Irrigation Declarations that must be obtained from all irrigated farms. The declaration provides information on the location, amount of irrigation needed, crop and type of land to be irrigated during the irrigation season, and covers the obligations related to irrigation. DSI develops irrigation plans by comparing estimates of irrigation water demand with the existing water resource potential and system capacity. Several thresholds are foreseen based on the General Irrigation Planning. When water availability falls below $70 \%$ of capacity, information is passed to DSI regional directorates and a water deficit situation is declared. An evaluation takes place with the participation of the WUO to agree restrictions that are subsequently announced to all water users. When the capacity is less than $30 \%$, a critical level is reached. At this stage, meetings are co-ordinated by DSI Regional Directorates, with the participation of local administrations, municipalities, WUO, farmers' organisations and leading farmers. Decisions taken depend on the current water situation in the region and include limiting watering to fixed orchards, irrigation with rotation, limited irrigation, night irrigation, not planting a second crop, or planting less water intensive crops. At the same time, some restrictions would apply to groundwater use.

Additional activities contribute to improved risk monitoring and preparedness outside of drought. For example, MGM's agricultural weather forecast webpage offers district level details, monthly agricultural weather bulletins monitor weather-related risks, and issues early warnings for adverse weather events. Meteorological observations are GIS enabled. Specialised maps, such as crop heat and cold resilience

${ }^{49}$ Stakeholder interview with the Agricultural committee of TUSIAD, 12 December 2019. 
maps, are published and inform crop-planting decision-making. Frost risk monitoring and drought analyses are also mapped and published. Commodity specialised services are also available to the agricultural sector. They include crop-specific harvest decision tools, as well as calculations of hourly dairy cattle heat stress or crop cooling demands. However, the extent to which farmers make use of these tools and services, and their penetration rates in the sector, are not clear.

Flood risk monitoring includes specific monitoring of precipitation, river flow and water bodies, and snow through DSI's network of 2000 hydro-meteorological observation stations. Precipitation records exist since 1980 and data are analysed to carry out risk assessment modelling and identify flood risk areas by combining hydrological data and models, and topographic land maps. The results are fed into flood hazard maps that are shared with AFAD, CSB, SYGM, and municipalities. The maps are also combined with flood observation data, and infrastructure and development information in the GIS enabled application TAMBIS (Turkish acronym for "Flood, Failure and Response Information System"), which is available on the internet and mobile phones. ${ }^{50}$ The application offers two functions. It can be used as a reporting tool for floods and infrastructure failures that complements DSl's flood monitoring and inspection activities of diversion and storage infrastructures and corrective interventions on riverbeds. The application also serves as a repository database for floods with information on past historical events.

In conjunction with the monitoring activities, research into risk preparedness for the agricultural sector in Turkey is supported by TAGEM's research mandate. Turkey's agricultural research five-year master plan, prepared by the MAF, defines four axes for publicly-funded research carried out at TAGEM in co-operation with international research networks. The axes consist of agricultural drought, sustainable use of natural resources, information systems, and capacity building (see also Box 4). Research carried out in other agencies also contributes to improved sector preparedness. For example, a research project was carried out at BDIARI on farmer perceptions of droughts, and the socioeconomic effects of drought in the Konya Plain Irrigation Project Region. The project aimed to understand how farmers and other value chain stakeholders perceive drought, to identify relevant practices to increase preparedness. The project's final report was submitted to relevant Ministries, however, the results of the report are not yet published or available to stakeholders.

In addition to their research activities, research institutions also carry out awareness-raising activities through the country's extension services. For example, since 2010, TAGEM's agricultural research master plan formally identified this role for its extension services, including building farmers' capacity to manage the effects of climate change on the sector. DSI also participates in knowledge sharing by organising symposiums and seminars, including for government agencies, most often on the theme of floods.

\subsection{Disaster response and crisis management}

Effective crisis management and response hinge on all actors knowing their responsibilities in the event of an emergency and communicating effectively, with the public sector taking a leadership role when the private sector is unable to cope. Crisis management and response to drought rely on identified chains of decision and effective co-ordination and communication across government and with stakeholders. AFAD is the first line respondent to general risks. It co-ordinates the preparation and implementation of disaster risk reduction plans and centralises disaster prevention and damage minimisation activities, disaster response and interagency co-ordination. Here again the role of government is central in Turkey in co-ordinating GD of different ministries and stakeholders, in analysing facts and notifying risk.

Drought is a slow-onset hazard and unlike other NHIDs such as earthquakes and storms, its initial stages are not easily detected as they require the monitoring of a combination of temperature, precipitation, evapotranspiration and soil moisture. Furthermore, drought poses challenges for government and farmers' response and management as its end depends on the uncertain replenishment of water levels. Nonetheless, as part of the Drought Strategy, it is the role of the RDK to trigger an early warning based on the collected data (Box 2). When triggered, the early warning is addressed to local Agricultural Drought Provincial Crisis Centers (hereafter Crisis Centres) and placed under the authority of Provincial Governors (TKYKK, 2013 ${ }_{[48]}$ ). Crisis Centres manage the local response. They declare the state of emergency and assign response tasks among agencies, and, at farm level, provide guidance for planting alternative crops and taking sanitary and

${ }^{50}$ https://apps.apple.com/app/dsi-tambis/id1125071528. 
phytosanitary measures to avoid pest and disease proliferation. Ex post, the Crisis Centres evaluate and communicate on-farm damages for central government compensation. Available information does not allow to document whether early warnings have been issued up to now and the actions encompassed by local responses.

In addition, an early warning system for weather related events is in place at the MGM, with alerts delivered through email, text messages, media, and social media platforms. For example, MGM's cell phone alert system can reach 4 million registered users. In 2019, early warnings were issued to 52000 stakeholders for 523 events, most of which were related to heavy rain.

MGM established its drought early warning system and webpage as a response to stakeholders' request. Early warnings are available on the MGM website. Based on SPI indices, the MGM informs government agencies when precipitation is low, water deficits are detected, and there is a risk of drought. ${ }^{51}$

When water shortages occur, Regional Directorates of DSI implement the General Irrigation Plans (see Section 3.4. In addition, Provincial governments also alert WUO and other stakeholders to drought formation so that contingency plans can be made, for example to alter cropping patterns and irrigation practices.

\subsection{Recovery and reconstruction}

Following a NHID, recovery and reconstruction efforts offer an opportunity for public and private stakeholders to evaluate systems' shortcomings and "build back better" by addressing underlying gaps in resilience, and building the capacities needed to manage natural hazards in the future (FAO, IFAD and WFP, 2019[12]). This requires all stakeholders - including producers - to learn from NHID in order to adjust DRM frameworks, policy measures and on-farm strategies with a view towards long-term resilience (OECD, 2014[11]; OECD, 2020[2]).

Recovery and reconstruction activities following NHID in Turkey range from large projects like repairing damaged infrastructure, down to programmes that support the financial recovery of farmers. Recovery from drought is more complex than recovery from other quick-onset natural hazards, in that recovery is predicated on a return to "normal" rainfall levels. Full-scale recovery from drought relies on either renewed access to water supplies, or else adaptation to circumstances such that access to water is no longer a threat, potentially requiring that farmers take measures designed to better position their operations for recovery. As such, recovery from drought events largely happens on farms. Government involvement mostly consists of the provision of inputs, of financial compensation and of activities under the Drought Strategy to better prepare the agricultural sector for the next drought.

Effective on-farm drought recovery depends to a large extent on how preceding risk management activities are carried out. This underscores the need for longer-term improvements in water resource availability through infrastructure rehabilitation and more efficient farm-level utilisation of available water resources that is, the most effective means of minimising the impact of drought and water crisis is to ensure that one does not occur in the first place, or ensuring that farm activities can continue even in the face of drought, taking management decisions where necessary with a view toward recovery. To some extent, the planning of current infrastructure investments and initiatives to improve water management capacity aims to reduce the impact of future drought events. But in general, Turkey's approach in this area follows its general strategy for agricultural growth, which puts a strong emphasis on irrigation and supports commodity output and water intensive crops (Table 1). Reliance on irrigation is also generally shared by farmers. In a survey of farmers taken after the 2007-08 drought, only around 30\% indicated that, should there be another drought, they would reduce their irrigation use and or switch to more efficient irrigation methods, while $17 \%$ would plant less water demanding crops (Engindeniz, 2013 ${ }_{[25]}$ ). The sector's dependence on irrigation reflects a water price structure that does not internalise the full cost of the resource.

Financial coping tools employed by farmers can include drawing on own reserves, payouts from insurance products, or public funds. In the agricultural sector, despite efforts to strengthen access to water resources, drought affects farm production and losses occur, and on-farm recovery relies on the efficient delivery of insurance compensation. Thus insurance indemnities are typically an effective coping tool, and agricultural insurance programmes in Turkey are improving and more widely available. TARSIM's claim and

51 The risk of drought corresponds to SPI index values below -0.51 . 
compensation process is set up to expedite compensation payments and facilitate rapid recovery and reconstruction of insured risks. According to the 2019 annual report of the agricultural insurance, drought compensation expenditure accounted for $0.7 \%$ and $0.3 \%$ of total compensation paid by TARSIM in 2018 and 2019 respectively. As detailed above, insurance for drought was introduced only recently and has limited participation among farmers. With respect to other government-supported coping tools, the Law on Assistance to Farmers Affected by Natural Disasters (Council of Ministers, 1977[68]), and its subsequent regulations (Council of Ministers, 2006[69]) foresee government compensation of damages to agricultural products or equipment that result from risks that are not insured. In the event of production losses or damage to agricultural facilities resulting from risks that are not covered by TARSIM, or are of an exceptional scale, farmers' losses may be compensated by the government. ${ }^{52}$ In such circumstances, Damage Determination Committees (DDC) are established at the district level to determine the type and place of the disaster, extent of damage to equipment and land, and the monetary value of damage in the field, and to inform Provincial DDC. The Provincial DDC prepare the list of eligible farmers and send it to the MAF to provide compensation aid in the form of credit subsidies, in-kind inputs or direct payments, technical assistance, or costs of repairing equipment.

However, the conditions for when compensation will be provided, including compensation timing and scale, are not announced in advance, making it difficult to assess their effectiveness as a coping mechanism. Other government funded instruments also support recovery and reconstruction, including credit subsidies and repayment deferrals, direct payments, technical assistance and contribution to the repair costs of equipment.

Post-event evaluation and assessment of drought events may take place within certain farming communities or WUOs, but it is not clear that such an assessment or evaluation is always conducted, nor is it clear how such assessments have led to improved future preparedness. Major disaster events involving AFAD response receive a post-event evaluation in its DRM cycle, but as noted above, drought events do not generally escalate to a water crisis level that would entail AFAD response and ex post evaluation and assessment.

The response and recovery process also involves critical analysis of the adequacy of institutions and processes in place to prepare for and respond to adverse events. There is substantial awareness in the government that climate change will continue to change the country's risk profile, so investments are needed now to successfully adapt in order to mitigate those effects in future. Turkey's Drought Strategy recognises the role of evaluating existing processes as a way to inform and shape future policy developments. However, the Drought Strategy was reconducted with no major changes in its most recent revision cycle and it is unclear if and how an evaluation process was carried out to construct the revision.

\section{Analysis and assessment}

\subsection{Disaster risk management in Turkey follows an all-hazards approach, but a more holistic implementation is needed that integrates various policy objectives with clearer roles and responsibilities among actors, including the private sector}

Multi-hazard and multi-sectoral DRM frameworks are important to ensure that trade-offs and interactions between disaster risks and strategies to manage those risks and wider DRM policies are taken into account (OECD, 2009[8]; OECD, 2018[70]). Through gradual implementation of the Sendai Framework, Turkey embraces an all-hazards approach for its natural risk management. Disaster risk reduction, prevention and mitigation and responses for large scale catastrophic events are co-ordinated by AFAD. However, drought management strategies are specific to agriculture and agricultural DRM activities for drought in Turkey are mainly shaped by agricultural policy frameworks. Turkey developed a Strategy for Combatting Agricultural Drought - the central component of the government's planning and preparedness for drought for the agricultural sector - providing a co-ordinated and integrated approach to prepare for, and manage, the adverse effects of droughts among agricultural stakeholders. Water management is a critical component of

52 Law No. 2090 on the Assistance to farmers who have suffered losses due to natural disasters (Council of Ministers, 1977[68]) and subsequent regulations (Council of Ministers, 2006[69]). 
managing drought risk. The National Water Plan, basin-based Drought Management Plans, basin-based Sectoral Water Allocation Plans, as well as General Irrigation Plans, all established by MAF General Directorates, are in place or under construction to better manage water resources and their use.

Efforts and reforms conducted in recent decades have been in the right direction, albeit resulting in a multiplicity of frameworks. In particular, there have been efforts to integrate risk management principles and plans for readiness for drought into national programmes (the Drought Strategy and National Irrigation Plans) and joint action plans of the central and provincial government (basin-based Drought Management and Sectoral Water Allocation Plans). Turkey's DRM for natural hazards can make further progress towards a more holistic approach by linking existing policy components in a cohesive way. It is unclear, for example, whether the objectives of the basin-based Drought Management Plans and the Strategy for Combatting Agricultural Drought are aligned. The absence of an integrated approach may lead to duplication and potential overlap, and may also result in a complex co-ordination situation at local level (OECD, 2019[21]; World Bank, 2020[71]). Diffuse governance among multiple agencies may also compound the lack of coherence and consistency, and weaken policy outcomes. In this sense, Turkey should harness the benefits of recent changes in MAF's structure to now include wider policy areas that are all critical for NHID risk management for the agricultural sector (e.g. water infrastructure, water management, meteorology).

Risk governance in Turkish agriculture would benefit from a more explicit identifications of the roles and responsibilities of each actor - central and local governments and the farm sector - involved in natural hazard risk management. Generally, it is an identified good practice that drought-specific plans should identify the roles and responsibilities of all stakeholders and define in advance the targets and menu of instruments (UNDP, 2011[72]). In Turkey, the government formulates and implements DRM strategies for natural hazard risk management, but the conditions under which policy responses are triggered are unclear. Clear conditions for triggering policy responses for DRM activities helps drive farmers' engagement in risk reduction and to incentivise farm-level adaptation to natural hazards that will be exacerbated by climate change (Ignaciuk, 2015[73]). In addition, current policies do not consider the role and responsibility of farmers to prevent, prepare for, and respond to disaster risk. While the Strategy for Combatting Agricultural Drought involves multiple actors in the planning process, interactions between public and private stakeholders remain consultative, and the Drought Strategy does not specify farmers' contribution to, and their role in, the DRM process, and thus transition steps are needed to ensure their participation. Without these signals, most farmers are unlikely to take appropriate action to improve their resilience to drought events. In addition, using the Drought Strategy to guide the farming sector's DRM would increase awareness of drought risks and the importance of preparedness in the farming sector and supply chain. To do so, the Drought Strategy should delineate clearly the roles and responsibilities of each stakeholder beyond government, to ensure that the impacts of droughts are effectively minimised.

A lack of clarity over responsibilities for managing disaster risks can also be overcome by eliminating barriers to stakeholder participation in DRM. From this standpoint, AFAD's endeavour to develop multi-hazard risk reduction plans (currently under development) at the national and the provincial level demonstrates progress towards more inclusive disaster risk governance. For drought in particular, impacts are often local, and therefore drought risk reduction interventions are more likely to succeed when drought risk management planning and initiatives are inclusive and driven by communities (UNDP, 2011 [72]). Turkey's Drought Strategy, which focuses on local level involvement, is an important policy practice for the agricultural sector. Moreover, agricultural Drought Provincial Crisis Centres are a valuable interface between the national and local government and other related local actors when planning drought responses. However, the involvement of stakeholders is still limited to a consultative role. Turkey's current exposure to drought suggests that more frequent interactions between local, regional, and national authorities, and farmers and other actors in the food supply chain, would help to create a culture of awareness of risk - as well as of stakeholders' roles and responsibilities - and preparedness to ensure effective response in time of crisis.

\subsection{Turkey's investments in strengthening natural hazard risk identification and assessment should be treated as a public good and used to raise stakeholders' awareness of their exposure to risks and inform their actions}

Building resilience to NHID requires risk identification and assessment, which in turn relies on monitoring and information collection. Drought impacts are often difficult to identify because the full effects of a drought can develop slowly over time, and longer-lasting impacts can be underestimated. Long periods without 
precipitation gradually erode farmers' coping capacities, in addition to crop failure and livestock losses that result from extended dry spells. Unlike sudden-onset natural hazards that occur abruptly (e.g. earthquakes), drought is a slow-onset hazard. As such, the progress of droughts can be monitored and anticipated. Therefore, when initial drought conditions are identified, information sharing with policy makers and farmers is important. Turkey's National Climate Change Action Plan recognises the importance of monitoring and analysing agricultural droughts, and the Strategy for Combatting Agricultural Drought prioritises drought data collection and structures for drought monitoring and assessment activities involving multiple actors. Turkey's range of natural hazard-related data repositories and research activities (for example, drought sensitivity modelling and vulnerability mapping, desertification modelling and erosion modelling and monitoring) also contributes to drought risk assessment. It is important that these assessments are accessible to all levels of government and used to inform the policy decision-making process for identified risks. For example, notwithstanding the many data collection tools and efforts, and in a context where droughts are increasing, the Drought Strategy was renewed without change in its most recent revision cycle. In this respect, going forward, it would be important to include an evaluation process that identifies measurable outcome indicators and involves stakeholders, in the Drought Strategy's renewal cycle. Doing so would allow this important document for drought resilience to remain relevant and targeted.

Few of Turkey's data repositories hold ex post information on agricultural economic losses as a result of natural hazards, although some information is available through insurance schemes and MAF's provincial directorates. Besides the AFET dataset, none of the public repositories contain critical economic loss data that would enable analysis of disaster impacts for the sector. The information base should be strengthened by including economic variables in existing repositories. Information on agricultural damage and loss could also be used more broadly to identify priority policy areas and to tailor and target risk management policies, in addition to sharing the risk data among public authorities.

Turkey can also strengthen the accessibility of risk identification and assessment outcomes for private sector stakeholders, and the public in general. While the public sector undertakes many of these risk identification and assessment activities in Turkey, links with the private sector and farmers are weak and stakeholders point to the lack of access to information on their exposure to climate-related risks. For example, beyond data repositories, access to hazard and vulnerability maps is also often limited to public agencies and government experts, and farmers are often unaware of these sources of information. Disseminating these relevant data and information to the public, the farming sector and other stakeholders could support evidence-based and risk-informed decisions that would strengthen stakeholders' resilience to NHID. Data on impacts (agricultural damage and losses) can also be used to alert stakeholders to their individual roles in disaster risk management.

\subsection{Turkey invests in structural and non-structural measures to mitigate and prevent drought risks, but water policies need be strengthened to better manage water resources}

There is a general understanding within government agencies of the importance of implementing ex ante approaches to disaster risk management. As Turkey's largest water user, the agricultural sector's role in mitigating and preventing water shortages and drought impacts is a recognised policy agenda. Today, most of the country's irrigated lands are watered with potentially inefficient irrigation methods (open-air irrigation canals) or via inefficient, aged irrigation facilities. Turkey's active investment in irrigation infrastructure including both rehabilitation of ageing water infrastructure and implementing modernised irrigation systems, such as drip irrigation and sprinklers (also more affordable methods) - is critical. However, investments in more efficient water infrastructure alone are likely to lead to increasing demand for water resources, unless accompanied by a strong water allocation and enforcement programme (Grafton et al., 2018[53]; OECD, 2016[23]). Thus for Turkey to ensure that these structural investments do not contribute to an unsustainable use of water supplies, it is important that the water allocation system be underpinned by a legal framework. At present, Turkey's Sectoral Water Allocation Plans are limited to five basins, and the lack of enforcement mechanisms results in farmers accessing water informally from surface water or from groundwater wells. Implementation of water allocation systems should also be sufficiently flexible to respond to and mitigate drought impacts. Water pricing is also important for Turkey, as it can incentivise water savings, and cover the costs of, and increase farmers' and other users' contributions to, the renewal and modernisation of irrigation infrastructure. In order to implement regulatory or economic water savings measures, installing water flow meters is particularly important. 
Aside from investment in structural measures, Turkey's various public research initiatives on climate change adaptation and on disaster risk management help the agricultural sector prepare, plan for, absorb, respond, recover from and more successfully adapt or transform in response to droughts and contribute to sector productivity and sustainability. Supported by several funding sources, research conducted at the regional, national and international scale enhances Turkey's adaptation and mitigation measures. That said, at the farm level, public extension services and farmer training are needed to facilitate the take-up of drought resistant crops and livestock, and support the transition to more water-frugal farming practices and the use of water-efficient irrigation methods. However, there is limited evidence to date of farm-level awareness and adaptive practices. Water use efficiency has been hard to achieve, and may be hindered by the lack of capacity and skilled farm labour. In other words, while water saving techniques can be affordable, their implementation requires skilled farmers and access to extension services. Non-structural measures, such as training programmes and capacity building opportunities, are necessary to reduce vulnerability to drought.

In addition to investing in measures that mitigate or prevent drought impacts, Turkey's reform of agricultural insurance has provided farmers with more options for ex-ante risk management tools. The current subscription rate is only around $23 \%$ but growing, in response to insurance premium subsidies and a hightech web-based system that expedites indemnity payments and faster recovery - increasing the attractiveness for farmers. However, the Law on Assistance to Farmers Affected by Natural Disasters (Council of Ministers, 1977[68]), and its subsequent regulations (Council of Ministers, 2006[69]) foresee public compensation for damage to agricultural products or equipment resulting from risks that are not insured, reducing the incentives for farmers to adopt prevention and mitigation measures. It is important that ex post disaster compensation criteria are announced in advance and limited to catastrophic events to incentivise farmers to integrate insurance or other prevention and mitigation measures into their farm management plans. As insurance take-up widens, other risk management strategies including crop diversification, and adaptation through conversion to water-frugal crops should continue to be part of the sector's portfolio of instruments for long-term resilience. Evidence from countries where recourse to insurance is widespread points to the potential for riskier behaviour at the expense of long-term resilience ${ }^{53}$ and hence to the need to take this risk into account when designing insurance support measures.

Adapting crops to basin climate conditions and soil categories is important to build drought resilience. ${ }^{54}$ However, farmers' uptake of preventative or mitigating measures may be hindered by the current agricultural policy framework that encourages commodity output through border protection and measures such as the Strategic Crops Scheme. Achieving policy coherence for efficient water use and drought resilience requires a shift away from output based support towards support for more sustainable production methods (for example, adoption of water-saving practices and less water-intensive crops).

\subsection{While the Government centralises disaster response, more could be done to support on- farm response capacities and encourage farm sector participation in a shared responsibility for a resilient recovery}

Turkey's restructuring of its institutions has helped the country to better respond to emergency situations. AFAD co-ordinates a whole-of-government response to large scale, and mostly sudden and life-threatening, disasters. However, AFAD's remit does not encompass droughts. This may be explained by the slow-onset nature of drought, which requires an adapted response timeline. Moreover, because the damage caused by drought is gradual and human casualties from drought are generally low, they fall below the trigger levels for an emergency response by AFAD.

However, droughts have an outsized impact on the livelihoods of the most vulnerable populations subsistence farmers and the rural poor - given their limited capacity to manage risk (UNDP, 2011 [72]). At the

\footnotetext{
${ }^{53}$ Subsidised insurance has been found to weaken incentives to adopt farm-level risk management practices (Schoengold, Ding and Headlee, 2015[85]), to increase irrigation water withdrawals (Deryugina and Konar, 2017[86]), and to discourage the long-term farm-level adaptation to changing climate (Annan and Schlenker, 2015[86], Chen and Dall'Erba, 2018[87] (Ignaciuk, 2015[73]). Innovation and research into drought-tolerant crops are discouraged (Miao, $2020[87])$. Hence reliance on insurance to manage drought risk may actually harm the sector's ability to confront future droughts (Baldwin and Casalini, 2021 [84]).
}

${ }^{54}$ Also confirmed in stakeholder interview with the World Bank office in Ankara, 10 December 2019. 
other end of the spectrum, the effects of droughts on market-oriented farmers can spread to domestic consumers, including the food processing industry, as well as to agro-food exports. In order to sustain business continuity and sector productivity, a system is necessary to swiftly respond to and recover from the impacts of drought. The Drought Strategy offers a platform for building capacities and networks for managing drought; for example, by defining and agreeing in advance the roles and responsibilities of stakeholders for drought risk management. Furthermore, other government responses, such as the thresholds that define the different drought levels or water shortages, should be shared; for example, in communications on the Drought Strategy, so that agricultural actors can act accordingly. Turkey also provides support to farmers based on the Law on Assistance to Farmers Affected by Natural Disasters and its subsequent regulations (Council of Ministers, 1977[68]; Council of Ministers, 2006[69]). Support trigger criteria should be defined in advance and clearly communicated to farming communities so that farmers can make more informed DRM decisions.

Finally, ex post assessment of drought impacts is an important step in the process for strengthening resilience and building back better. However, it is not clear that post-disaster evaluations of DRM processes are undertaken regularly in Turkey. The renewal of the Strategy without substantial changes may call for an improved and more transparent evaluation process. Assessment should cover not only the impacts of adverse events on the farm business, farmers' livelihoods, farm facilities, but also the governance of DRM (including awareness and co-ordination), and the functioning of the social systems Lessons learnt serve as the basis for allocating resources more effectively, and for adapting and designing a strategy to reduce future disaster risks by incorporating a Build Back Better approach.

\section{Conclusion}

This case study shows examples of good practices in Turkey's systems and processes for managing natural hazards affecting agriculture, including drought, which contribute to the sector's resilience.

Turkey's DRM governance and policy frameworks seek to ensure that the agricultural sector is better prepared for adverse events and can respond effectively when these occur. Turkey's national disaster risk management framework, co-ordinated by AFAD, covers multiple hazards. MAF's new structure, including water infrastructure, water management, and meteorology DGs, can also help better co-ordinate DRM planning for droughts and other natural hazards. Moreover, Turkey's Drought Strategy and subsequent action plans offer structured risk planning both at national and regional levels. However, notwithstanding these good practices, Turkey lacks a holistic multi-hazard agricultural DRM system and the frameworks remain government-centred. There is a need for an overarching vision that explicitly links various national plans to ensure that policy objectives are aligned, measures are streamlined, and roles and responsibilities identified for all actors in disaster risk management. A multi-stakeholder evaluation of the development and operation of existing plans would be a first step in this direction. The DRM system also needs to be updated and assessed periodically, building on lessons learnt from previous adverse events.

Turkey is also making substantial efforts on data collection to better identify and assess drought risks. These include drought risk monitoring activities based on the Drought Strategy, which inform policy makers' disaster risk management decisions. Turkey's use of agricultural drought crisis centres at provincial level is a valuable interface between the national and local government and other local stakeholders when assessing and planning for drought risks. The involvement of stakeholders in the drought risk assessment process demonstrates how participatory processes can be employed to prepare for adverse events. Turkey's range of natural hazard-related data repositories and research activities (e.g. meteorological and hydrological data collections, drought sensitivity modelling and vulnerability mapping) also contribute to drought risk assessment. These efforts must be promoted with improved data accessibility and dissemination in order to increase awareness of the risk environment and inform decision-making processes that help both public and private actors more effectively prevent, mitigate and respond to risk. Wider access to data on adverse events also strengthens the evidence base on which Build Back Better strategies can be planned.

Policymakers recognise the benefits of prevention and ex ante approaches for managing the risks posed by natural hazards. In particular, efforts have been devoted to investing in both conventional and modernised irrigation infrastructure to increase water use efficiency. In addition, Turkey's proactive research activities, with collaboration at regional, national and international levels, on heat-tolerant breeds and crop varieties, 
smart technologies for irrigation, and soil management under drought risk all help increase on-farm risk prevention and mitigation. Further, the enhancement of agricultural insurance, with the introduction of the district-based drought yield insurance scheme, can help improve farmers' recovery from NHIDs. In particular, improvements to the TARSIM insurance scheme facilitate faster and more accurate payouts. That said, many of these improvements are too recent to evaluate their effectiveness. In order to realise the benefits of these actions, implementation and continuous assessment and evaluation will be needed, along with a continued commitment to adjust where needed.

Turkey places a strong emphasis on access to water and irrigation, not only to increase water use efficiency, but also as a means of increasing productivity. Effective management of water demand by agriculture, as the country's largest user of water resources, is critical to mitigate and prevent drought impacts. Accompanying structural measures, regulatory and economic instruments - such as a water allocation system that includes enforcement measures and water pricing - can incentivise on-farm water use efficiency, and thus should be explored. To do so, installing water meters, particularly in areas that experience water shortages, is essential.

Policy coherence also requires continuous attention. For example, currently, policies both aim to reduce the farm sector's vulnerability to drought and encourage the production of water intensive crops, which sends contradictory signals to farmers. The transition away from commodity support to the provision of sector-wide services that enhance the sector's capacity to prepare, prevent, absorb and reconstruct are steps in the direction of sustainable productivity growth. This could include more support for R\&D on drought resistant varieties, encouraging the adoption of water-saving crop varieties, and providing education and training to build on-farm capacities to adopt and implement drought resilient management methods.

Finally, on-farm awareness, preparedness and adaptation to drought risks are key for reducing farming communities' vulnerability and building agricultural resilience. Farm-level DRM practices can also prevent further escalation of water stress, but income and educational disparities in rural communities could hinder the capacity to better manage increasing natural hazard risks. Targeted training programmes and extension services can, for example, transfer knowledge and skill-up farmers on the use of efficient irrigation techniques and drought-adapted farming practices. Indeed, all the measures outlined above will need to be implemented in association with capacity building for the agricultural sector. 


\section{Acronyms and Institutions}

\begin{tabular}{|c|c|}
\hline AFAD & Disaster and Emergency Management Presidency (Ministry of Interior) AFAD \\
\hline BDIARI & $\begin{array}{l}\text { Bahri Dağdaş International Agricultural Research Institute in Konya. (MAF-TAGEM) Bahri Dagdas } \\
\text { International Agricultural Research Institute (tarimorman.gov.tr) }\end{array}$ \\
\hline ÇEM & $\begin{array}{l}\text { General Directorate for Combating Desertification and Erosion (MAF) General Directorate of Combating } \\
\text { Desertification and Erosion (tarimorman.gov.tr) }\end{array}$ \\
\hline CIMMYT & International Maize and Wheat Improvement Centre https://www.cimmyt.org/ \\
\hline CSB & Ministry of Environment and Urbanisation T.C. Cevre ve Sehircilik Bakanlığı (csb.gov.tr) \\
\hline DSI & State Hydraulics Works (MAF) Devlet Su İșleri Genel Müdürlüğü (dsi.gov.tr) \\
\hline FAO & United Nations Food and Agriculture Organization http://www.fao.org/home/en \\
\hline GEF & Global Environment Facility https://www.thegef.org/ \\
\hline ICARDA & International Dry Areas Agricultural Research Institute https://www.icarda.org/ \\
\hline İLBANK & Development and investment bank affiliated to CSB I ILBANK (ilbank.gov.tr) \\
\hline IWWIP & $\begin{array}{l}\text { International Winter Wheat Improvement Program (Joint programme of ICARDA and CIMMYT } \\
\text { http://www.iwwip.org/) }\end{array}$ \\
\hline MAF & Ministry of Agriculture and Forestry of the Republic of Turkey (https://www.tarimorman.gov.tr/) \\
\hline MGM & Turkish State Meteorological Service (MAF) Tarımsal Hava Tahmini (mgm.gov.tr) \\
\hline SUEN & Turkish Water Institute (MAF) $\underline{\text { SUEN - Türkiye Su Enstitüsü }}$ \\
\hline SYGM & $\begin{array}{l}\text { General Directorate for Water Management (MAF) General Directorate of Water Management } \\
\text { (tarimorman.gov.tr) }\end{array}$ \\
\hline DASK & Turkish Catastrophe Insurance Pool https://www.dask.gov.tr/tcip/index.html \\
\hline TAGEM & $\begin{array}{l}\text { General Directorate of Agricultural Research and Policies (MAF) General Directorate of Agricultural } \\
\text { Research and Policies (tarimorman.gov.tr) }\end{array}$ \\
\hline TARSIM & State Agricultural Insurance (MAF-TRGM) TARSIM (tarsim.gov.tr) \\
\hline TUIK & Turkish Statistical Institute (https://www.tuik.gov.tr/en/) \\
\hline TUSIAD & Turkish Industry and Business association TÜSIAD (tusiad.org) \\
\hline TRGM & GD Agricultural Reform (MAF) General Directorate Of Agricultural Reform (tarimorman.gov.tr) \\
\hline WUO & Water Users Organisations \\
\hline
\end{tabular}




\section{References}

AFAD (2019), Strategic Plan 2019-2023, Ministry of Interior,

https://en.afad.gov.tr/kurumlar/en.afad/e Library/plans/AFAD 19 23-StrategicPlan Eng.pdf.

Baglee, A. et al. (2013), Climate Risk Case Study Pilot Climate Change Adaptation - Market Study: Turkey, European Bank for Reconstruction and Development, https://www.ebrd.com/downloads/sector/sei/turkeyadaptation-study.pdf.

Baldwin, K. and F. Casalini (2021), "Building the resilience of Italy's agricultural sector to drought", OECD Food, [83] Agriculture and Fisheries Papers, Organisation for Economic Co-Operation and Development (OECD), http://dx.doi.org/10.1787/799f1ad3-en.

Berk, A. (2013), Processor driven integration of small-scale farmers into value chains in Turkey, Regional Office for Europe and Central Asia, FAO, http://www.fao.org/3/a-au850e.pdf.

Berktay, A. and B. Nas (2008), The effective use of water in Konya (Turkey) closed basin, Surveying Geology \& [74] Mining Ecology Management, https://search.proquest.com/openview/171c8b6f2d526710ceb14835d437d8e2/1 ?cbl=1536338\&pqorigsite $=$ gscholar (accessed on 2020).

Casalini, F., M. Bagherzadeh and E. Gray (2021), "Building the resilience of New Zealand's agricultural sector to [82] floods", OECD Food, Agriculture and Fisheries Papers, No. 160, OECD Publishing, Paris, https://dx.doi.org/10.1787/dd62d270-en.

Climate Change Post (2020), Turkey - Droughts, https://www.climatechangepost.com/turkey/droughts/ (accessed on 19 August 2020).

Council of Ministers (2006), "Regulation on providing aid to farmers after acts of God", Official Journal No. 26272, 27 August 2006, http://www.fao.org/faolex/results/details/en/c/LEX-FAOC068520 (accessed on 29 April 2021).

Council of Ministers (1977), "Law No. 2090 on the Assistance to farmers who have suffered losses due to natural disasters.", Yayimlandigi R. Gazete No. 15987, 5 July 1977, http://www.fao.org/faolex/results/details/en/c/LEX-FAOC023720/ (accessed on 29 April 2021).

CSB (2018), Seventh National Communication of Turkey under the UNFCCC, https://unfccc.int/sites/default/files/resource/496715 Turkey-NC7-17th\%20National\%20Communication\%20of\%20Turkey.pdf (accessed on 28 October 2020).

CSB (2010), Republic of Turkey Climate Change Action Plan 2011-2023, https://policy.asiapacificenergy.org/sites/default/files/National\%20Climate\%20Change\%20Action\%20Plan\% 202011-2023.pdf (accessed on 7 November 2020).

CSB (2010), Turkey’s National Climate Change Adaptation Strategy 2010-2023, https://webdosya.csb.gov.tr/db/iklim/editordosya/iklim degisikligi stratejisi EN(2).pdf (accessed on 7 November 2020).

Demircan, M. et al. (2017), Climate Change Projections for Turkey: Three Models and Two Scenarios, pp. 2243 , https://www.mgm.gov.tr/FILES/genel/makale/44 Climate\%20Change\%20Projections\%20for\%20Turkey.pdf.

Deryugina, T. and M. Konar (2017), "Impacts of Crop Insurance on Water Withdrawals for Irrigation", Advances in Water Resources, Vol. 110, pp. 437-444, http://dx.doi.org/10.1016/j.advwatres.2017.03.013. 
DSI (2020), "State Hydraulic Works", Annual Report,

https://cdniys.tarimorman.gov.tr/api/File/GetFile/425/Konulcerik/759/1107/DosyaGaleri/DS\%C4\%B0\%20202 0-yili-faaliyet-raporu.pdf (accessed on 21 June 2021).

Engindeniz, S. (2013), Effects and adaptation measures of drought in turkish agriculture: a case study of tomato farmers in Izmir, Turkey, 24th International Scientific-Expert Conference of Agriculture and Food Industry, https://www.researchgate.net/publication/311616093 EFFECTS AND ADAPTATION MEASURES OF D ROUGHT IN TURKISH AGRICULTURE A CASE STUDY OF TOMATO FARMERS IN IZMIR TURKE $\underline{Y}$.

EU (2019), European Joint Programme on agricultural soil management, https://cordis.europa.eu/programme/id/H2020 LC-SFS-20-2019 (accessed on 4 July 2021).

EU (2007), The EU Floods Directive (Directive 2007/60/EC), https://eur-lex.europa.eu/legalcontent/EN/TXT/?qid=1595260598704\&uri=CELEX:32007L0060 (accessed on 2020).

EU (2000), The EU Water Framework Directive (Directive 2000/60/EC ), https://eur-lex.europa.eu/legalcontent/EN/TXT/?uri=CELEX:32000L0060.

FAO (2021), Global Soil Partnership, http://www.fao.org/global-soil-partnership/en/ (accessed on 2 July 2021).

FAO (2018), Biodiversity of Turkey, http://www.fao.org/3/ca1517en/CA1517EN.pdf.

FAO (2009), International Treaty on Plant Genetic Resources for Food and Agriculture, http://www.fao.org/plant- [56] treaty/overview/texts-treaty/en/ (accessed on 4 July 2021).

FAO Investment Centre (2016), Turkey: Water along the food chain, FAO, Rome, http://www.fao.org/3/ai5991e.pdf.

FAO, IFAD and WFP (2019), Strengthening resilience for food security and nutrition: A Conceptual Framework for Collaboration and Partnership among the Rome-based Agencies, Food and Agriculture Organization of the United Nations (FAO), the International Fund for Agricultural Development (IFAD) and the World Food Programme (WFP), https://docs.wfp.org/api/documents/WFP-0000062320/download/.

G7 Agriculture Ministers (2017), G7 Bergamo Agriculture Ministers' Meeting Communiqué 14-15 October 2017 Empowering Farmers, Developing Rural Areas and Enhancing Cooperation to Feed the Planet, http://www.g7italy.it/en/documenti-ministeriali.

GFDRR (2011), "Global Facility for Disaster Reduction and Recovery", Turkish Catastrophe Insurance Pool, http://documents1.worldbank.org/curated/en/853431468188946296/pdf/97450-BRI-Box391476B-PUBLICpoolstuddy-DFI-TCIP-Jan11.pdf (accessed on July 2020).

Grafton, R. et al. (2018), "The paradox of irrigation efficiency", Science, Vol. 361/6404, pp. 748-750, http://dx.doi.org/10.1126/science.aat9314.

Gray, E. and K. Baldwin (2021), "Building the resilience of the United States' agricultural sector to extreme floods", OECD Food, Agriculture and Fisheries Papers, No. 161, OECD Publishing, Paris, https://dx.doi.org/10.1787/edb6494b-en.

Gruère, G., M. Shigemitsu and S. Crawford (2020), "Agriculture and water policy changes: Stocktaking and alignment with OECD and G20 recommendations", OECD Food, Agriculture and Fisheries Papers, No. 144, OECD Publishing, Paris, https://dx.doi.org/10.1787/f35e64af-en.

Gurenko, E. et al. (2006), Earthquake Insurance in Turkey, The World Bank, http://dx.doi.org/10.1596/978-08213-6583-0.

Gurkan, H. et al. (2021), "Estimating the potential impact of climate change on sunflower yield in the Konya province of Turkey", The Journal of Agricultural Science, pp. 1-13, http://dx.doi.org/10.1017/s0021859621000101. 
IBRD (2016), Valuing Water Resources in Turkey, The World Bank,

http://documents1.worldbank.org/curated/en/600681476343083047/pdf/AUS10650-REVISED-PUBLICTurkey-NCA-Water-Valuation-Report-FINAL-CLEAN.pdf.

Ignaciuk, A. (2015), "Adapting Agriculture to Climate Change: A Role for Public Policies", OECD Food, Agriculture and Fisheries Papers, No. 85, OECD Publishing, Paris, https://dx.doi.org/10.1787/5js08hwvfnr4en.

IPCC (2007), Climate Change 2007: Synthesis Report. Contribution of Working Groups I, II and III to the Fourth Assessment Report of the Intergovernmental Panel on Climate Change [Core Writing Team, Pachauri, R.K and Reisinger, A. (eds.)], IPCC, Geneva, Switzerland.

Keser, M. et al. (2017), "Genetic gains in wheat in Turkey: Winter wheat for dryland conditions", The Crop Journal, Vol. 5/6, pp. 533-540, http://dx.doi.org/10.1016/i.cj.2017.04.004.

Khan, M. et al. (2016), "Wheat landraces production on farm level in Turkey: Who is growing in where?", Pakistan Journal of Agricultural Sciences, Vol. 53/01, pp. 159-169, http://dx.doi.org/10.21162/pakjas/16.3754.

Kibaroglu, A. (2020), "The role of irrigation associations and privatization policies in irrigation management in Turkey", Water International, Vol. 45/2, pp. 83-90, http://dx.doi.org/10.1080/02508060.2020.1719382.

Komuscu, A., A. Erkan and S. Oz (1998), , Climatic Change, Vol. 40/3/4, pp. 519-545, http://dx.doi.org/10.1023/a:1005349408201.

MAF (2021), Basin-based Strategic Crop Scheme, list of commodities supported in 2021, https://www.tarimorman.gov.tr/Haber/4840/2021-Yili-Havzalarda-Desteklenecek-Urun-Listeleri (accessed on 27 April 2021).

MAF (2019), "National Water Plan 2019-2023”, Ulusal su plani (2019-23), http://www.fao.org/faolex/results/details/en/c/LEX-FAOC202337/ (accessed on 16 June 2021).

MGM (2021), Drought analysis, https://www.mgm.gov.tr/veridegerlendirme/kuraklik-analizi.aspx?d=aylik\&k=pni (accessed on 26 April 2021).

MGM (2020), Annual Drought Situation, http://kuraklikizle.mgm.gov.tr/ (accessed on 27 April 2021).

Miao, R. (2020), "Climate, Insurance and Innovation: The Case of Drought and Innovations in Drought-Tolerant Traits in US Agriculture", European Review of Agricultural Economics, https://doi.org/10.1093/erae/jbaa010 (accessed on 26 June 2020).

NASA (2021), Turkey experiences intense drought, https://earthobservatory.nasa.gov/images/147811/turkeyexperiences-intense-drought (accessed on 2021).

NOAA - NCEI (2021), "Definition of Drought", National Centers for Environmental Information, https://www.ncdc.noaa.gov/monitoring-references/dyk/drought-definition (accessed on 29 April 2021).

OECD (2021), Agricultural Policy Monitoring and Evaluation 2021: Addressing the Challenges Facing Food Systems, OECD Publishing, Paris, https://dx.doi.org/10.1787/2d810e01-en.

OECD (2021), Agriculture and Water Policies: Main characteristics and evolution from 2009 to 2019, https://www.oecd.org/agriculture/topics/water-and-agriculture/documents/oecd-water-policies-country-noteturkey.pdf.

OECD (2021), OECD Economic Surveys: Turkey 2021, OECD Publishing, Paris, https://dx.doi.org/10.1787/2cd09ab1-en.

OECD (2020), Agricultural Policy Monitoring and Evaluation 2020, OECD Publishing, Paris, https://dx.doi.org/10.1787/928181a8-en. 
OECD (2020), "Nature-based solutions for adapting to water-related climate risks", OECD Environment Policy

Papers, No. 21, OECD Publishing, Paris, https://dx.doi.org/10.1787/2257873d-en.

OECD (2020), Strengthening Agricultural Resilience in the Face of Multiple Risks, OECD Publishing, Paris, https://dx.doi.org/10.1787/2250453e-en.

OECD (2019), OECD Environmental Performance Reviews: Turkey, OECD Publishing, Paris, https://doi.org/10.1787/9789264309753-en.

OECD (2018), Assessing Global Progress in the Governance of Critical Risks, OECD Reviews of Risk Management Policies, OECD Publishing, Paris, https://dx.doi.org/10.1787/9789264309272-en.

OECD (2018), OECD Economic Surveys: Turkey 2018, OECD Publishing, Paris, https://doi.org/10.1787/eco surveys-tur-2018-en.

OECD (2016), Innovation, Agricultural Productivity and Sustainability in Turkey, OECD Food and Agricultural Reviews, OECD Publishing, Paris, https://dx.doi.org/10.1787/9789264261198-en.

OECD (2016), Mitigating Droughts and Floods in Agriculture: Policy Lessons and Approaches, OECD Studies on Water, OECD Publishing, Paris, https://dx.doi.org/10.1787/9789264246744-en.

OECD (2015), The OECD Principles on water governance, https://www.oecd.org/governance/oecd-principleson-water-governance.htm (accessed on 4 July 2021).

OECD (2014), Boosting Resilience through Innovative Risk Governance, OECD Reviews of Risk Management Policies, OECD Publishing, Paris, https://dx.doi.org/10.1787/9789264209114-en.

OECD (2014), Recommendation of the Council on the Governance of Critical Risks, OECD Publishing, Paris, http://www.oecd.org/gov/risk/recommendation-on-governance-of-critical-risks.htm.

OECD (2011), Evaluation of Agricultural Policy Reforms in Turkey, OECD Publishing, Paris, https://dx.doi.org/10.1787/9789264113220-en.

OECD (2011), Managing Risk in Agriculture: Policy Assessment and Design, OECD Publishing, Paris, https://dx.doi.org/10.1787/9789264116146-en.

OECD (2009), Managing Risk in Agriculture: A Holistic Approach, OECD Publishing, Paris, https://dx.doi.org/10.1787/9789264075313-en.

OECD/FAO (2021), Building Agricultural Resilience to Natural Hazard-induced Disasters: Insights from Country Case Studies, OECD Publishing, Paris, https://dx.doi.org/10.1787/49eefdd7-en.

Özerol, G., H. Bressers and F. Coenen (2012), "Irrigated agriculture and environmental sustainability: an alignment perspective", Environmental Science \& Policy, Vol. 23, pp. 57-67, http://dx.doi.org/10.1016/j.envsci.2012.07.015.

PRIMA (2019), "Patnership for Research and Innovation in the Mediterreanean Area", Efficient use and management of conventional and non-conventional water resources through smart technologies applied to improve the quality and safety of Mediterranean agriculture in semi-arid areas - WATERMED 4.0, https://www.watermed-project.eu/docs/WATERMED pu d2 1 v1 3.pdf.

SBB (2019), "Presidency of Strategy and Budget", Eleventh Development Plan (2019-2023), http://www.sbb.gov.tr/wp-content/uploads/2020/06/Eleventh Development Plan-2019-2023.pdf (accessed on August 2020).

Schnitkey, G. (2020), Revenue Protection: The Most Used Crop Insurance Product, Department of Agricultural and Consumer Economics, University of Illinois at Urbana-Champaign, https://farmdocdaily.illinois.edu/2020/11/revenue-protection-the-most-used-crop-insurance-product.html. 
Schoengold, K., Y. Ding and R. Headlee (2015), "Impact of AD HOC Disaster and Crop Insurance Programs on the Use of Risk-Reducing Conservation Tillage Practices", American Journal of Agricultural Economics, Vol. 97/3, pp. 897-919, https://doi.org/10.1093/ajae/aau073 (accessed on 29 June 2020).

Shigemitsu, M. and E. Gray (2021), "Building the resilience of Japan's agricultural sector to typhoons and heavy rain", OECD Food, Agriculture and Fisheries Papers, No. 159, OECD Publishing, Paris, https://dx.doi.org/10.1787/4ed1ee2c-en.

TARSIM (2020), 2019 Annual Report, https://web.tarsim.gov.tr/havuz/dokumanGoster.doc? key =588A0CCE2D31D152E41507A43EF483DC605 80037HJH2V33IL4PV28V07109012021 (accessed on 29 April 2021).

TARSIM (2020), District Based Drought Yield Insurance, https://web.tarsim.gov.tr/havuz/subPageEng? key =25F89BEAC40CF3A3A0938178D4EC4C2A2685340M A1T4G96GDOO7G9ST2410102019 (accessed on 19 June 2020).

TARSIM (2005), "Agricultural Insurance Law (translation)”, Official gazette 25852 of 21-06-2005, https://web.tarsim.gov.tr/havuz/dokumanGoster.doc? key =6D7415BE31795E0576A7CE18FEDB4F2E361 368E28MSTMV13TI6C93CC6F24062015 (accessed on 29 April 2021).

TARSIM (multiple), Annual reports, https://web.tarsim.gov.tr/havuz/subPageEng? key =6D7415BE31795E0576A7CE18FEDB4F2E706432SJL 9K6S03D8MJSQS72RF24062015.

Tatar, O. (2016), "Climate change impacts on crop production in Turkey", Lucrări Ştiinţifice - vol. 59(2)/2016, seria Agronomie, Vol. 59/2, pp. 135-140, http://www.uaiasi.ro/revagrois/PDF/2016-2/paper/2016-59(2) 25en.pdf.

TCIP (2016), "Turkish Natural Catastrophe Insurance Pool”, Activity Report, https://www.dask.gov.tr/tcip/content/annualReport/DASK16 ENGdizgiSON.pdf (accessed on July 2020).

TKYKK (2013), "Agricultural Drought Management Coordination Board”, National Drought Management Policies - Activities for combatting agricultural drought in Turkey, https://www.droughtmanagement.info/literature/UNW-DPC NDMP Country Report Turkey 2013.pdf.

TUIK (2020), Crop production statistics, http://www.turkstat.gov.tr/PreTablo.do?alt id=1001 (accessed on 14 September 2020).

TUIK (2016), Agricultural Holding Structure Survey, https://data.tuik.gov.tr/en/displaybulletin/?bulletin=agricultural-holding-structure-survey-2016-24869 (accessed on 23 October 2020).

Turkish Red Crescent (2006), 1999 Marmara earthquake case study, https://www.ifrc.org/PageFiles/93724/report-turkey.pdf.

UNDP (2011), Mainstreaming Drought Risk Management, https://www.undp.org/content/undp/en/home/librarypage/environmentenergy/sustainable land management/mainstreaming droughtriskmanagementaprimer.html.

UNISDR (2015), Sendai Framework for Disaster Risk Reduction 2015 - 2030, United Nations Office for Disaster Risk Reduction, https://www.unisdr.org/files/43291 sendaiframeworkfordrren.pdf (accessed on 22 August 2018).

Unlu, A., N. Kapucu and B. Sahin (2010), "Disaster and crisis management in Turkey: a need for a unified crisis management system", Disaster Prevention and Management: An International Journal, Vol. 19/2, pp. 155174, http://dx.doi.org/10.1108/09653561011037977.

WMO (2012), "World Meteorological Organization", Standardized Precipitation Index User Guide, https://library.wmo.int/doc num.php?explnum id=7768. 
World Bank (2020), Turkey Resilient Landscape Integration Project - Project Information Document, http://documents1.worldbank.org/curated/en/549311586266635333/pdf/Concept-Project-InformationDocument-PID-Turkey-Resilient-Landscape-Integration-Project-TULIP-P172562.pdf.

World Bank (2019), Turkey Irrigation Modernization, https://projects.worldbank.org/en/projects-

[60] operations/project-detail/P158418?lang=en (accessed on 4 July 2021).

Yapp, E. and J. Dewdney (2021), Turkey, https://www.britannica.com/place/Turkey (accessed on 12 April 2021). [18] 


\section{OECD FOOD, AGRICULTURE AND FISHERIES PAPERS}

This report was declassified by the Working Party on Agricultural Policies and Markets of the Committee for Agriculture in September 2021 and was prepared for publication by the OECD Secretariat.

This report, as well as any data and any map included herein, are without prejudice to the status of or sovereignty over any territory, to the delimitation of international frontiers and boundaries and to the name of any territory, city or area.

The statistical data for Israel are supplied by and under the responsibility of the relevant Israeli authorities. The use of such data by the OECD is without prejudice to the status of the Golan Heights, East Jerusalem and Israeli settlements in the West Bank under the terms of international law.

Comments are welcome and can be sent to tad.contact@oecd.org. 